\title{
Phytochemistry, gas chromatography-mass spectrometry analysis and in vitro anti-bacterial activities of Desplatsia dewevrei (De Wild. \& T. Durand)
}

\author{
Oghale Ovuakporie-Uvo ${ }^{1}$, MacDonald Idu ${ }^{1}$ and Anne 0. Itemire ${ }^{2}$ \\ ${ }^{1}$ Phytomedicine Unit. Department of Plant Biology and Biotechnology. University \\ of Benin. Benin City, PMB 1154. Edo State. Nigeria. \\ ${ }^{2}$ Department of Medical Microbiology. University of Benin. Benin City. Nigeria.
}

\begin{abstract}
Phytochemicals have been reported to have direct and/or indirect influence on the antibacterial potentials of useful plants. The present study was aimed at determining the phyto-components by traditional methods and GC-MS analysis alongside testing the anti-bacterial activities of Desplatsia dewevrei leaves and fruits. The maceration of $500 \mathrm{~g}$ of Desplatsia dewevrei powder in methanol yielded $5.7 \mathrm{~g}$ of extract. Qualitatively coumarins were found to be richly present in the leaves while, quinones were most evidently present in the fruits of Desplatsia dewevrei. Quantitative analyses show that the phenolic and tannic acid contents of Desplatsia dewevrei may be the chief compounds responsible for the antibacterial activity of the plant. GC-MS results of Desplatsia dewevrei fruits and leaves respectively showed Gas Chromatograms having 33 and 63 peaks representing different phyto-compounds. Of the 33 and 63 phyto-compounds, Cyclohexanepropanol, alpha.,2,2,6-tetramethyl and Farnesyl bromide were recurrent at different retention time. Although Desplatsia dewevrei showed no zone of inhibition for gram negative bacteria, its inhibitory effect on gram positive bacteria is significant. In conclusion, $D$. dewevrei is a phytochemical rich plant. However, a further study on the antibacterial effect of Desplatsia dewevrei using solvent extracts other than methanol is recommended for future incorporation in drug development.
\end{abstract}

Keywords: Desplatsia dewevrei; Phytochemistry; GC-MS; Antibacterial.
Received

July 31, 2018

Accepted

August 28, 2018

Released

August 31, 2018

Full Text Article

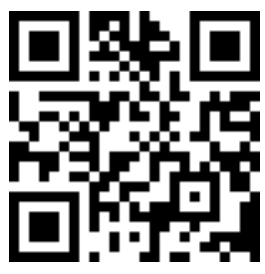

ORCID

D 0000-0002-1394-5658 Oghale OvuakporieUvo

(D) 0000-0002-5082-1988 MacDonald Idu

D 0000-0003-0977-9121

Anne 0. Itemire 


\section{Introduction}

Herbal medicine is the study of medicinal plants either classified as trees, shrubs, herbs, climbers or creepers for the purpose of enhancing and restoring health. Medicinal plants play a major role in making available useful products in the health sector, agricultural and food industries worldwide (Harisaranraj et al., 2009). At present, global interest in medicinal herbs triggered by improved researches into pharmacognosy and the ability to treat various diseases is on the rise (Dhivya and Kalaichelvi, 2017). Western medicines are developed from diverse ethno-medicines after thorough chemical and pharmaceutical screenings (Boopathi and Sivakuma, 2011). Phytochemical screenings help researchers see at a glance the various chemical compounds present in a plant material. Phytochemicals are not principally required for the sustenance of life but confer extra health benefits against certain plant pathogens (Mathew et al., 2012). Identifying, elucidating and quantifying structures of different chemical constituents in any plant are basic tasks in drug discovery procedure (Riaz et al., 2012; Siyan et al., 2010). Modern and advanced approaches to drug discovery, such as combinatorial chemistry, and computer-based molecular modeling designs cannot replace the essential role of natural products in drug discovery (Andriano et al., 2012; Abok and Manula, 2017).

Gas Chromatograph Mass Spectrometry (GCMS) is one of the compatible techniques useful in identifing the bioactive constituents of long chain, branched chain hydrocarbons, alcohols, acids, esters, etc present in crude plant materials (Sathiyabalan et al., 2014). In GC-MS analyses, unknown organic compounds in a complex mixture can be determined by interpretation and also by matching the spectra with reference spectra on texts (Ronald Hites, 1997; Rajeswari and
Rani, 2015) and chemistry databases available online.

Amongst several known medicinal plants is Desplatsia dewevrei. Desplatsia dewevrei is a forest tree characterized by leaves about $12-31 \mathrm{~cm}$ long and 4-12 cm broad, cordate on each side at base, with large white or yellow flowers (Keay, 1989). Desplatsia dewevrei which has been listed as one of the major non-wood forest localized products of Nigeria (Osemeobo and Ujor, 1999); is an underutilized forest tree (Keay, 1989) of gross economic use among a legendary tribal in Southern Nigeria. D. dewevrei have been used over the years by these locals from time immemorial. A few studies on the scientific researches on $D$. dewevrei have been reported (Ovuakporie-Uvo et al., 2017; 2018). However, the phytochemistry, Gas chromatography - Mass spectroscopy (GC-MS) and antibacterial activities of the plant have not been reported. Thus, this study was aimed investigating the phytochemicals present in the methanol extract of Desplatsia dewevrei and its ability to inhibit bacterial activities in vitro.

\section{Materials and methods}

\section{Plant collection and authentication}

Fresh Leaves and fruits of Desplatsia dewevrei were harvested from a forest in Ugbogiobo village located in Edo State, Nigeria. Plant materials were identified and authenticated at the Herbarium unit in the Department of Plant Biology and Biotechnology, University of Benin, Benin City and assigned a voucher number UBHm0283.

\section{Plant preparation and}

Fresh leaves and fruits were rinsed severally under running water and air-dried in a shady place for 3 weeks. The fruits were diced evenly before drying. Plant materials were further dried in a hot air oven at $55^{\circ} \mathrm{C}$ for 
$1 \mathrm{~h}$ to make them dry crispy then blended using a mechanical blender. 500 $\mathrm{g}$ of plant powder was weighed macerated in $3.5 \mathrm{~L}$ of methanol with occasional stirring. After $72 \mathrm{~h}$, the extract was filtered using a muslin cloth. The extract was collected and evaporated to dryness using a W4000 rotary evaporator and a BK-FD10S tabletop freeze drier at $\leq-56{ }^{\circ} \mathrm{C}$. The final residue obtained was then subjected to GC-MS analysis.

\section{Qualitative phytochemistry}

Alkaline reagent test: One gram of Crude extract was mixed with $2 \mathrm{~mL}$ of $2 \%$ solution of $\mathrm{NaOH}$. An intense yellow colour were formed which turned colourless on addition of few drops of diluted acid which indicated the presence of flavonoids.

Ferric chloride test: To $2 \mathrm{~mL}$ of filtrate was added $3 \mathrm{~mL}$ of distilled water followed by 2 few drops of $5 \%$ ferric chloride solution. An intense coloration was formed indicating the presence of phenols.

Test for cardiac glycosides: $4 \mathrm{~mL}$ of the crude extract was mixed with $2 \mathrm{~mL}$ of glacial acetic acid and $1 \mathrm{~mL}$ of concentrated $\mathrm{H}_{2} \mathrm{SO}_{4}$ acid. Absence of green-blue coloration indicated presence of cardiac glycoside.

Test for terpenoids: One gram of the Crude extract was dissolved in 2 $\mathrm{ml}$ of chloroform and evaporated to dryness. To this, $2 \mathrm{~mL}$ of concentrated $\mathrm{H}_{2} \mathrm{SO}_{4}$ was added and heated for about 2 min. A greyish colour indicated the presence of terpenoids.

Test for tannins: Tannins were tested for following method adopted by Ladan et al. (2014).

Test for saponins: Frothing test as described by Evans (1996) was used to detect the presence of Saponins.
Determination of anthraquinones: $50 \mathrm{mg}$ of the ground leaf sample was weighed. A volume of $50 \mathrm{~mL}$ of distilled water was added and allowed to stand for $15 \mathrm{~min}$. Thereafter, mixture was brought to boil at $70{ }^{\circ} \mathrm{C}$ for $1 \mathrm{~h}$ thereafter cooled and filtered. The clear solution was read at $450 \mathrm{~nm}$.

Test for phlobatannins: One gram of extract was added to $2 \mathrm{~mL}$ of $1 \%$ $\mathrm{HCl}$ and boiled. Presence of a red precipitate was taken as an evidence for the presence of phlobatannins.

Test for alkaloids: $1 \mathrm{~mL}$ of extract was treated with few drops of Dragendorff's reagent. Orange brown precipitate indicated the presence of alkaloids.

Test for steroids: Five drops of concentrated $\mathrm{H}_{2} \mathrm{SO}_{4}$ was added to $1 \mathrm{ml}$ of each extract. A red colouration indicated the presence of steroids.

Other methods not mentioned were carried out following their prescribed methods as stated by AOAC (2005), Obadoni and Ochuko (2001), and Sofowora (2008).

\section{Quantitative phytochemistry \\ Determination of total}

phenolic content: The total phenolic content was determined using the FolinCiocalteau Method as described by Cicco et al. (2009).

Determination of total tannins: Tannin content was dertermined by Folin-Denis Method (Polshettiwar and Ganjiwale, 2007).

\section{Determination of proanthocya-}

nidin: The determination of proanthocyanidin was carried out according to the method of Sun et al. (1998).

Determination of total flavonoid content: The total flavonoid 
content was determined using the method of Miliauskas et al. (2004).

\section{Gas chromatography-mass spectrometry (GC-MS) analysis}

The gas chromatography-mass spectrometry (GC-MS) analysis of the Desplatsia dewevrei was done using a GCMS (Model; QP2010 series, Shimadzu, Tokyo, Japan) following methods described by Iyamah et al. (2017). Interpretation of mass spectrum of plant extracts were carried out by comparing spectrums of the peaked compounds in the plant extract with the spectra of the National Institute of the data base of National Institute of Standard and Technology (NIST) library, PubChem and other online chemistry libraries database.

\section{Antibacterial studies \\ Preparation of extract concen-}

tration: Three hundred milligram per milliliter of three extracts (aqueous, methanol and n-hexane extracts) was used. Methanol and n-hexane extracts were solubilized using dimethyl sulphoxide and diluted with sterile distilled water to required concentration.

Preparation of nutrient agar plates: Nutrient agar was prepared according to manufacturer's instruction. Thirty milliliter volume was poured into standard disposable Petri-dishes and allowed to solidify. The excess surface moisture was dried in hot air oven at $56^{\circ} \mathrm{C}$ for $15 \mathrm{~min}$.

Bacterial isolates: The bacterial isolates used for this experiment were collected from the pharmaceutical microbiology laboratory, Faculty of Pharmacy, University of Benin. They were already identified bacterial isolates of Escherichia coli (Ec1, Ec2 and Ec3), Klebsiella species (Kleb1, Kleb2 and Kleb3), Pseudomonas aeruginosa (Ps1, Ps2 and Ps3), Staphylococcus aureus
(Sa1, Sa2, Sa3, Sa4, Sa5 and Sa6) and Bacillus subtilis (Bs1, Bs2, Bs3 and Bs4). A total of 19 isolates of both gram positive and gram negative bacteria were used.

Preparation of bacterial isolates: The collected bacterial isolates were sub-cultured into prepared dry sterile nutrient agar plates and were incubated at $37{ }^{\circ} \mathrm{C}$ for $24 \mathrm{~h}$ bacterial colonies were inoculated into quarter strength Ringer's solution and turbidity compared with $0.5 \mathrm{McF}$ arland standard.

Sensitivity testing: The prepared nutrient agar plates were inoculated with the three different bacterial isolates and properly labelled. Six wells were made using sterile $10 \mathrm{~mm}$ cork-borer on each nutrient agar plate and the wells were labelled. The base of each well was sealed with $0.025 \mathrm{~mL}$ molten nutrient agar. The wells were filled to $2 / 3$ with $0.2 \mathrm{~mL}$ of each 300 $\mathrm{mg} / \mathrm{mL}$ concentration of extracts as labelled per well. The extracts were allowed to absorb for $30 \mathrm{~min}$ and incubated right side up for $24 \mathrm{~h}$ at $37^{\circ} \mathrm{C}$. The zone of inhibition was measured using a pair of chloride and a transparent ruler. Further dilution was done for extract with zone of inhibition for minimum inhibitory concentration.

Results

\section{Plant extract yield}

The extraction of $500 \mathrm{~g}$ of Desplatsia dewevrei powder using methanol yielded approximately $5.7 \mathrm{~g}$ of extract.

\section{Qualitative phytochemistry \\ Coumarins are the most} abundantly present phytochemical in the leaves of Desplatsia dewevrei while quinones are richly abundant in the fruits of the plant as shown on Table 1. 
Table 1. Qualitative phytochemistry of Desplatsia dewevrei.

\begin{tabular}{lcc}
\hline Phytochemicals & Leaves & Fruits \\
\hline Flavonoids & + & + \\
Phenol & + & + \\
Cardiac glycosides & ++ & + \\
Terpenoids & + & + \\
Tannins & + & + \\
Saponins & ++ & - \\
Sterols & - & + \\
Quinones & + & +++ \\
Anthraquinone & - & - \\
Fixed oil & - & - \\
Coumarins & +++ & + \\
Phlobatannins & - & ++ \\
Alkaloids & + & - \\
\hline
\end{tabular}

Key: $+++=$ remarkably detected; $++=$ appreciably detected; $+=$ less detected; $-=$ not detected.

\section{Quantitative phytochemistry}

The leaves and fruits of Desplatsia dewevrei contain appreciable amount of phenolic and tannic contents as shown on Table 2 .

Table 2. Quantitative phytochemical studies of Desplatsia dewevrei

\begin{tabular}{ccc}
\hline Phytochemicals & Leaves & Fruits \\
\hline TPC & $44.79 \pm 3.00$ & $21.54 \pm 1.86$ \\
TFC & $25.25 \pm 0.88$ & $1.14 \pm 0.47$ \\
TTC & $50.46 \pm 0.38$ & $20.66 \pm 0.10$ \\
TPC & $0.431 \pm 0.004$ & - \\
\hline
\end{tabular}

Key: TPC-Total Phenolic content; TFC-Total Flavonoid Content; TTC-Total Tannic acid Content; TPC-Total Proanthocyanidin Content. 
33 peaks depicting different phyto-compounds were identified in the GC-MS analysis. A gas chromatogram shows the relative concentrations of various compounds eluted from a chemical substance as a function of retention time. The Gas Chromatogram of $D$. dewevrei methanol leaf extract is shown on Figure 1.

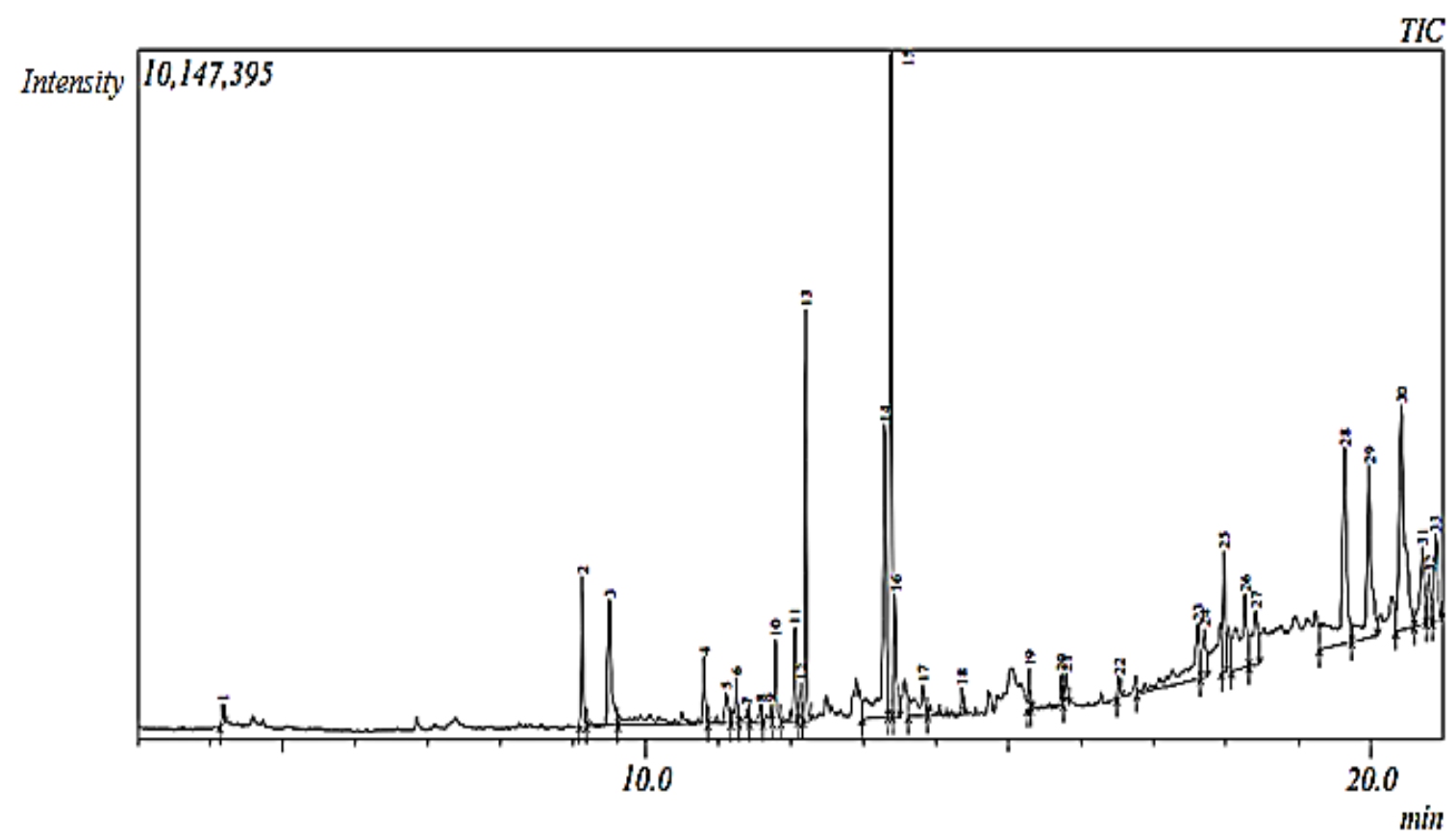

Figure 1. GC-MS chromatogram of Desplatsia dewevrei methanol leaf extract.

The GC/MS spectral results and comparison of results with library search successfully enabled the identification of the 33 compounds: The identification of phytochemical compounds in this study was based on the retention time, name of compound, molecular weight, molecular formula, peak area, nature of compound and their chemical structures as shown on Table 3. The results reveal the presence of mostly fatty acids, esters, alcohols and vitamin E. 


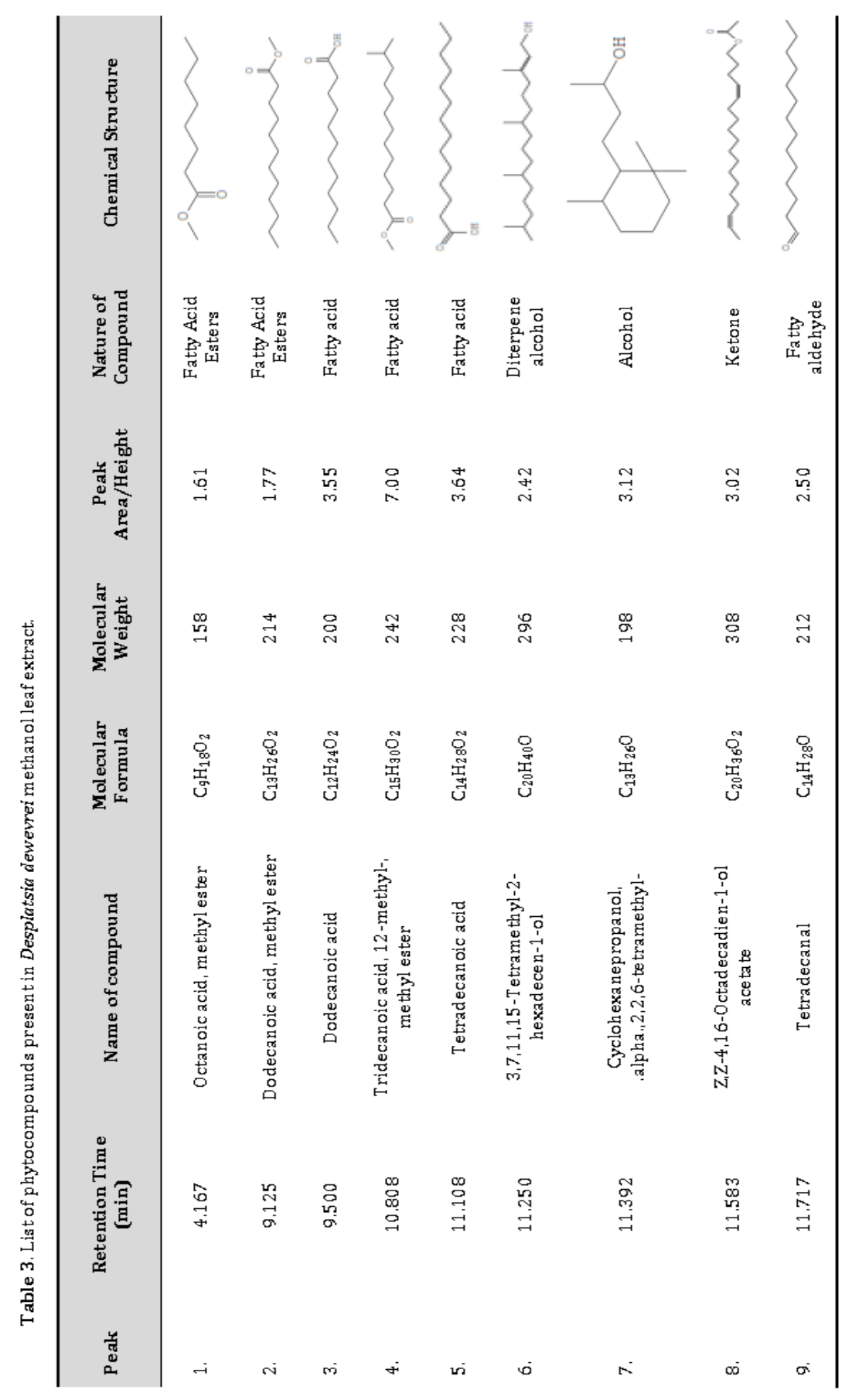

Braz. J. Biol. Sci., 2018, v. 5, No. 10, p. 373-404. 


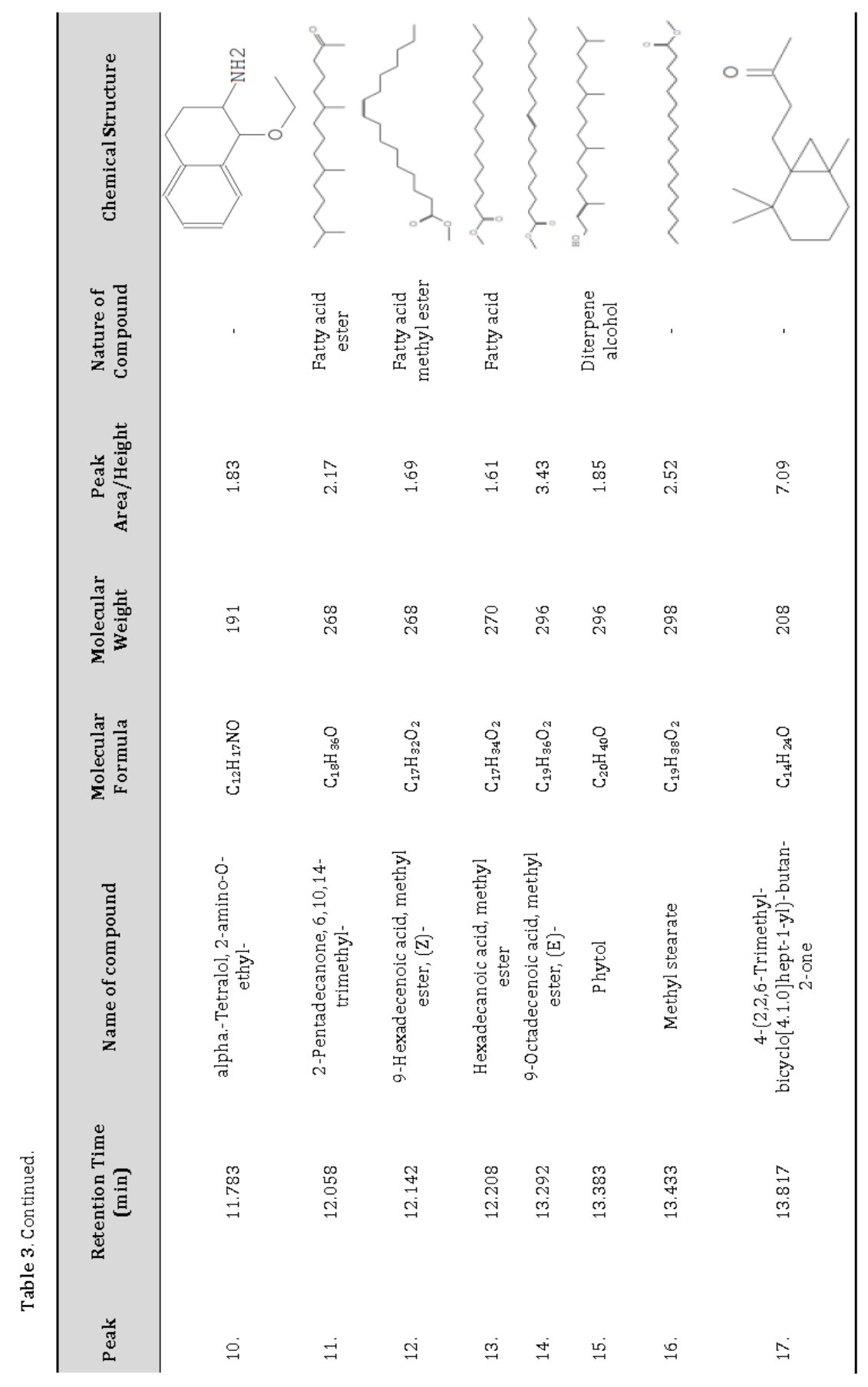

Braz. J. Biol. Sci., 2018, v. 5, No. 10, p. 373-404. 


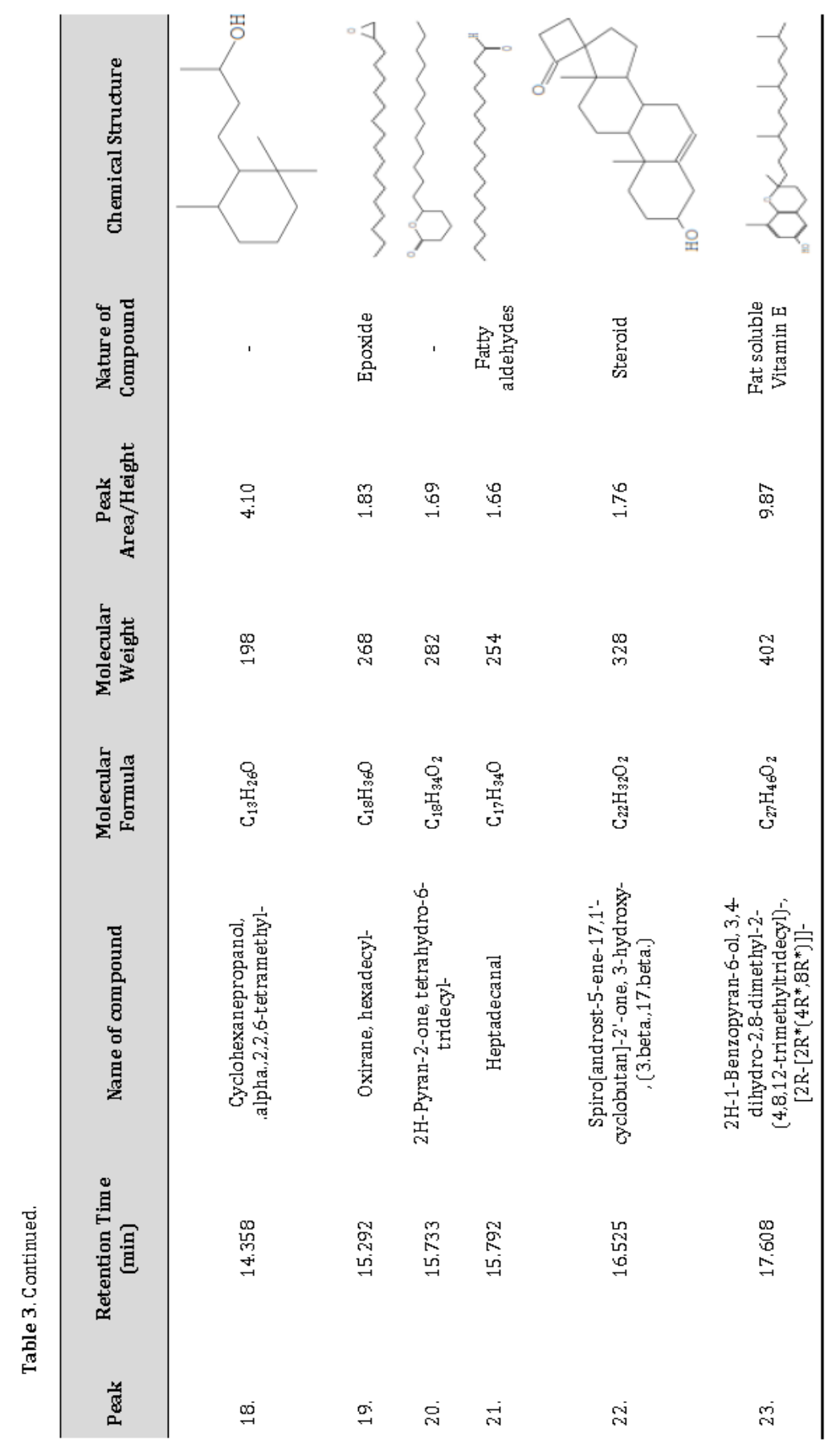

Braz. J. Biol. Sci., 2018, v. 5, No. 10, p. 373-404. 


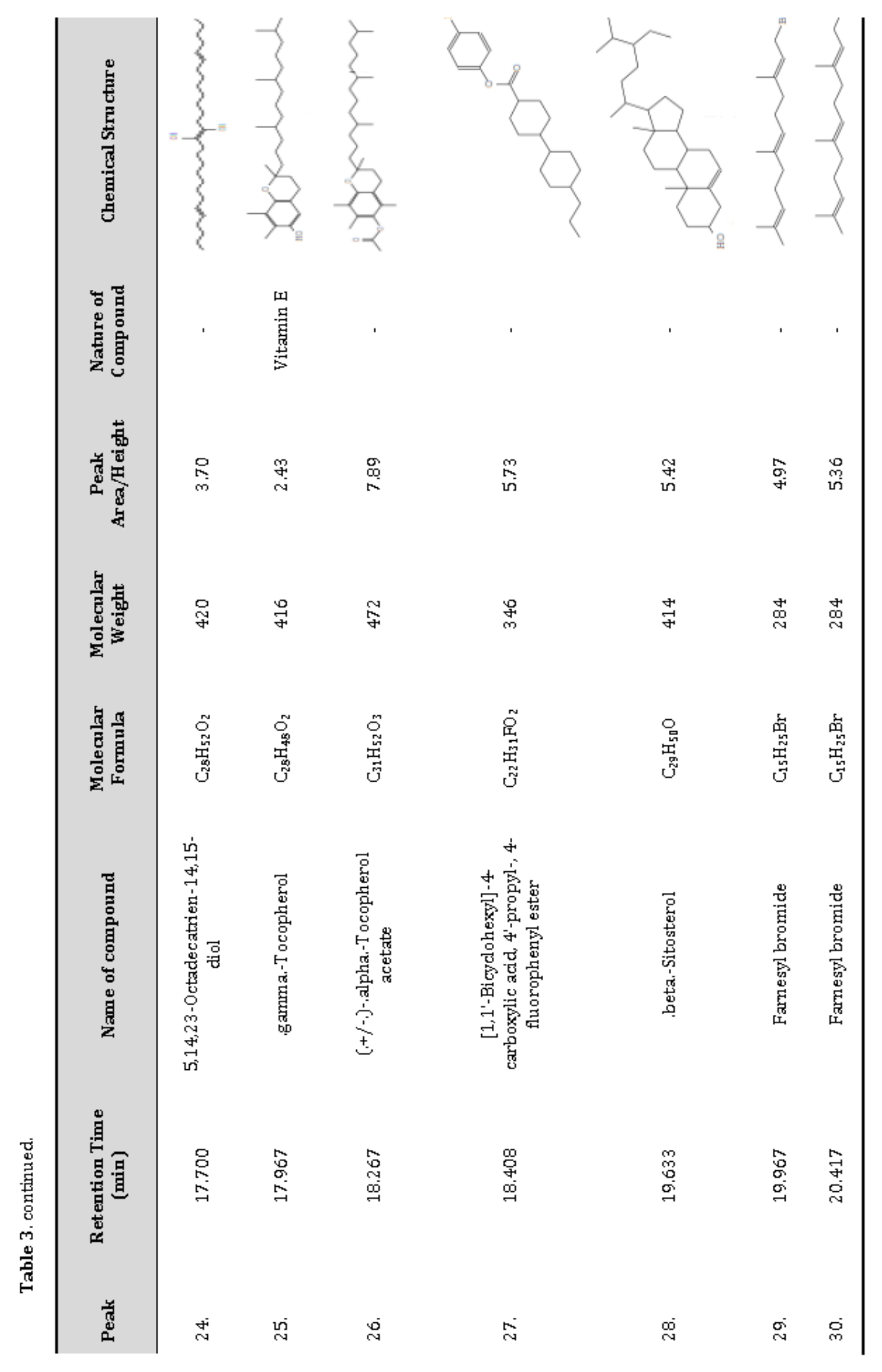

Braz. J. Biol. Sci., 2018, v. 5, No. 10, p. 373-404. 


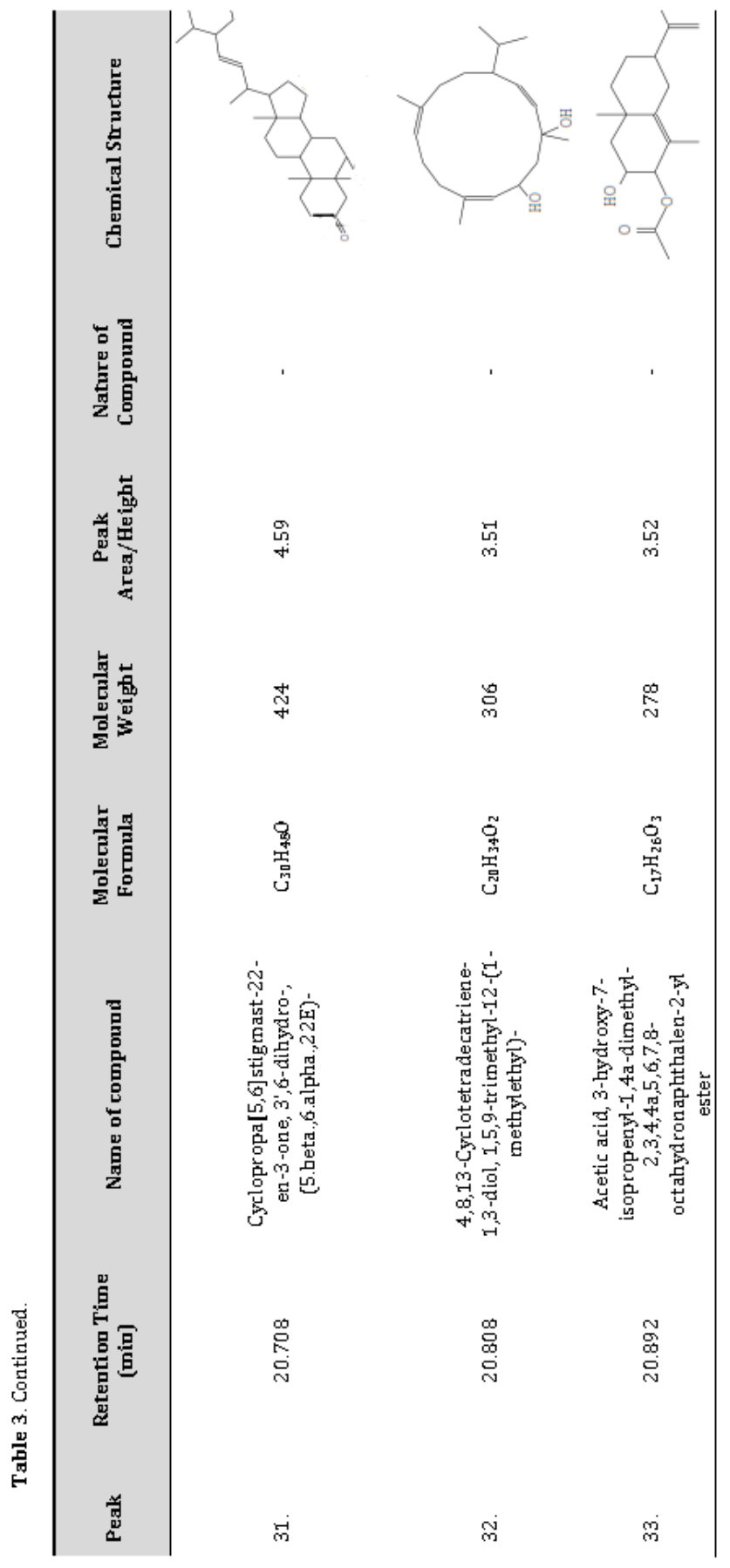

Braz. J. Biol. Sci., 2018, v. 5, No. 10, p. 373-404. 
Figure 2 shows a gas chromatogram displaying sixty three phyto-compounds found present in the methanol fruit extract of Desplatsia dewevrei. The chromatogram shows that the fruits of the plant contain more phyto-compounds than its leaves.

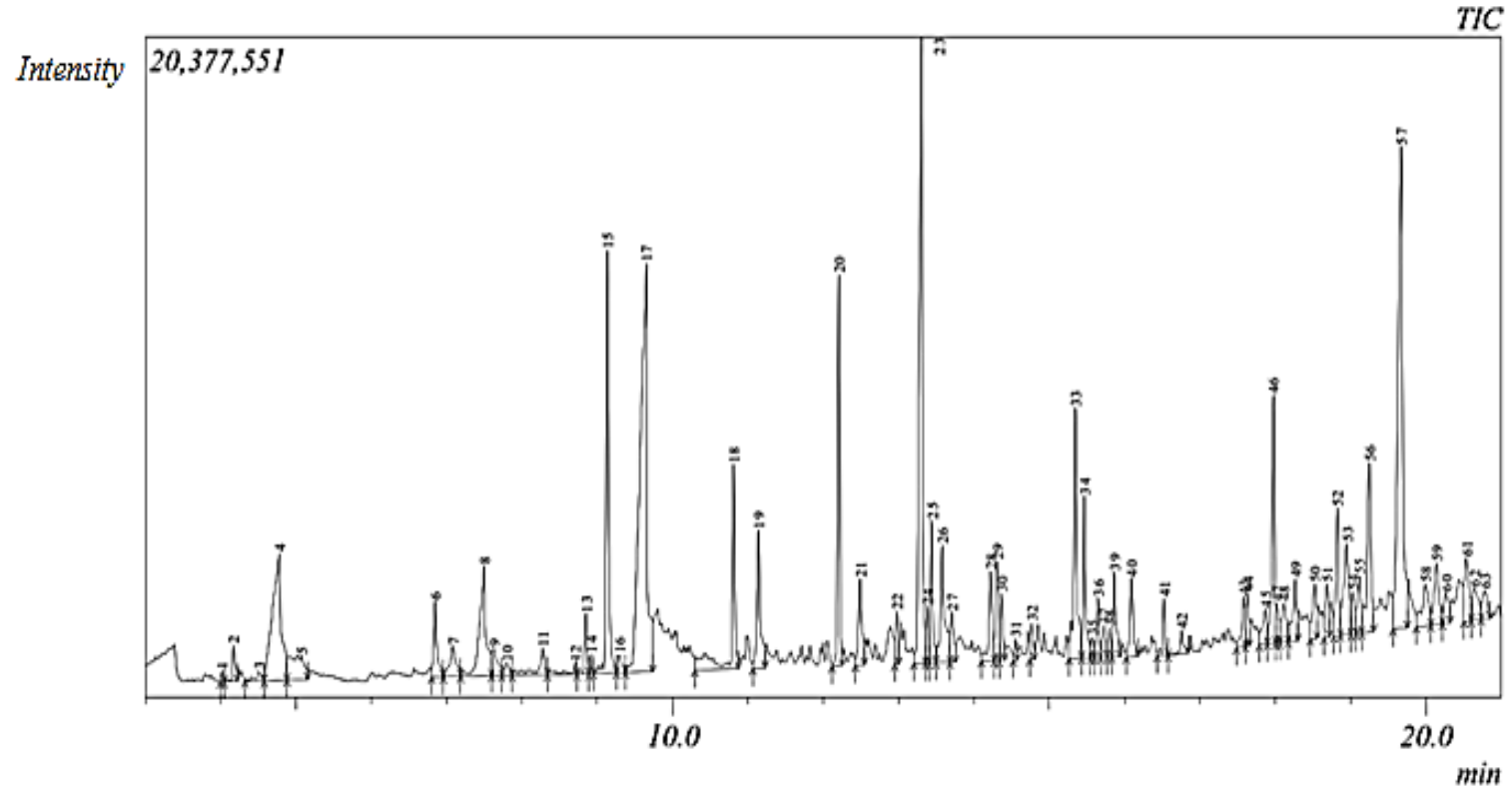

Figure 2. GC-MS chromatogram of Desplatsia dewevrei methanol fruits extract.

Table 4 shows the names of the compounds, retention time and nature of the 63 phyto-compounds found present in the methanol fruit extract of Desplatsia dewevrei. 


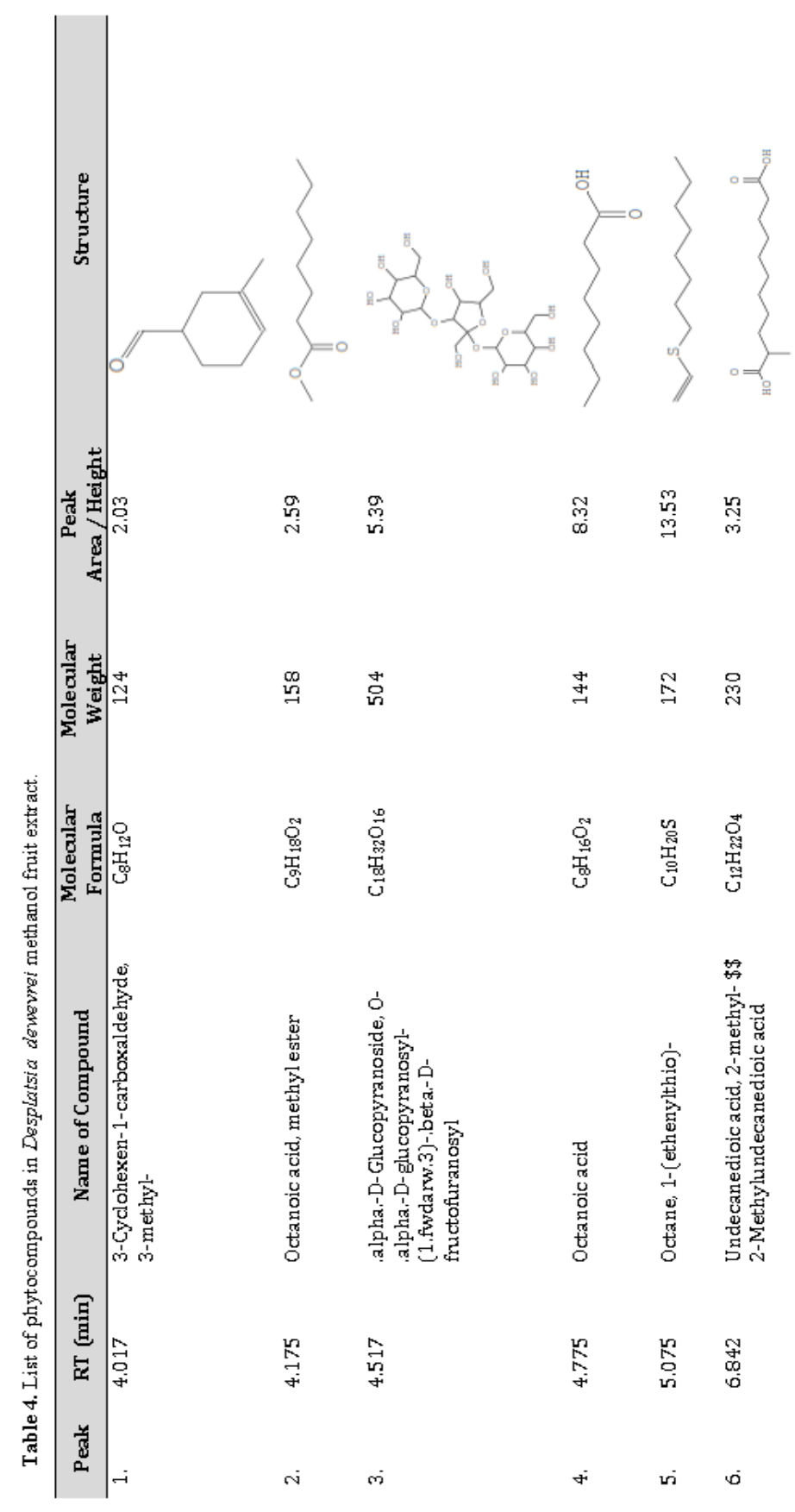

Braz. J. Biol. Sci., 2018, v. 5, No. 10, p. 373-404. 


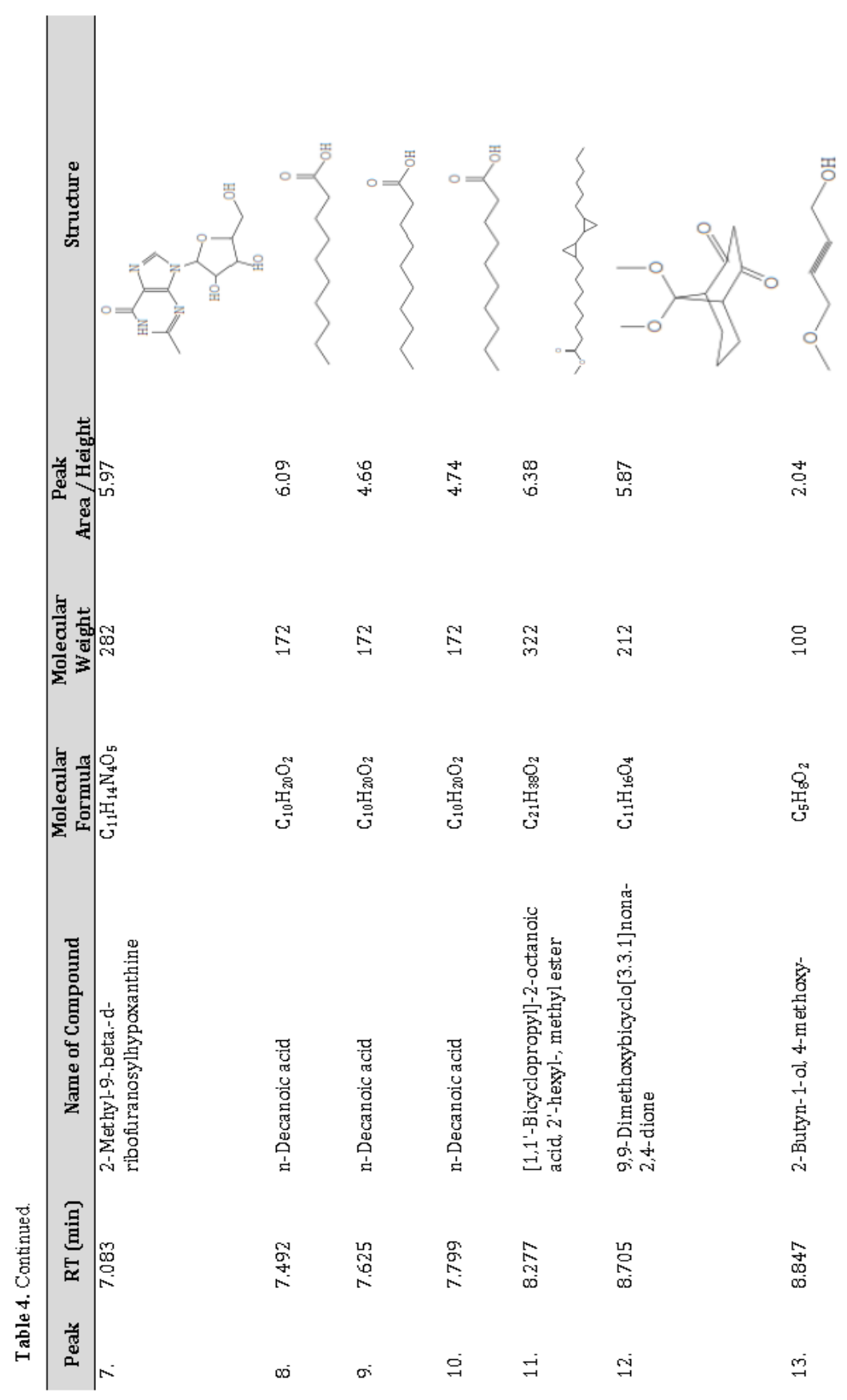

Braz. J. Biol. Sci., 2018, v. 5, No. 10, p. 373-404. 


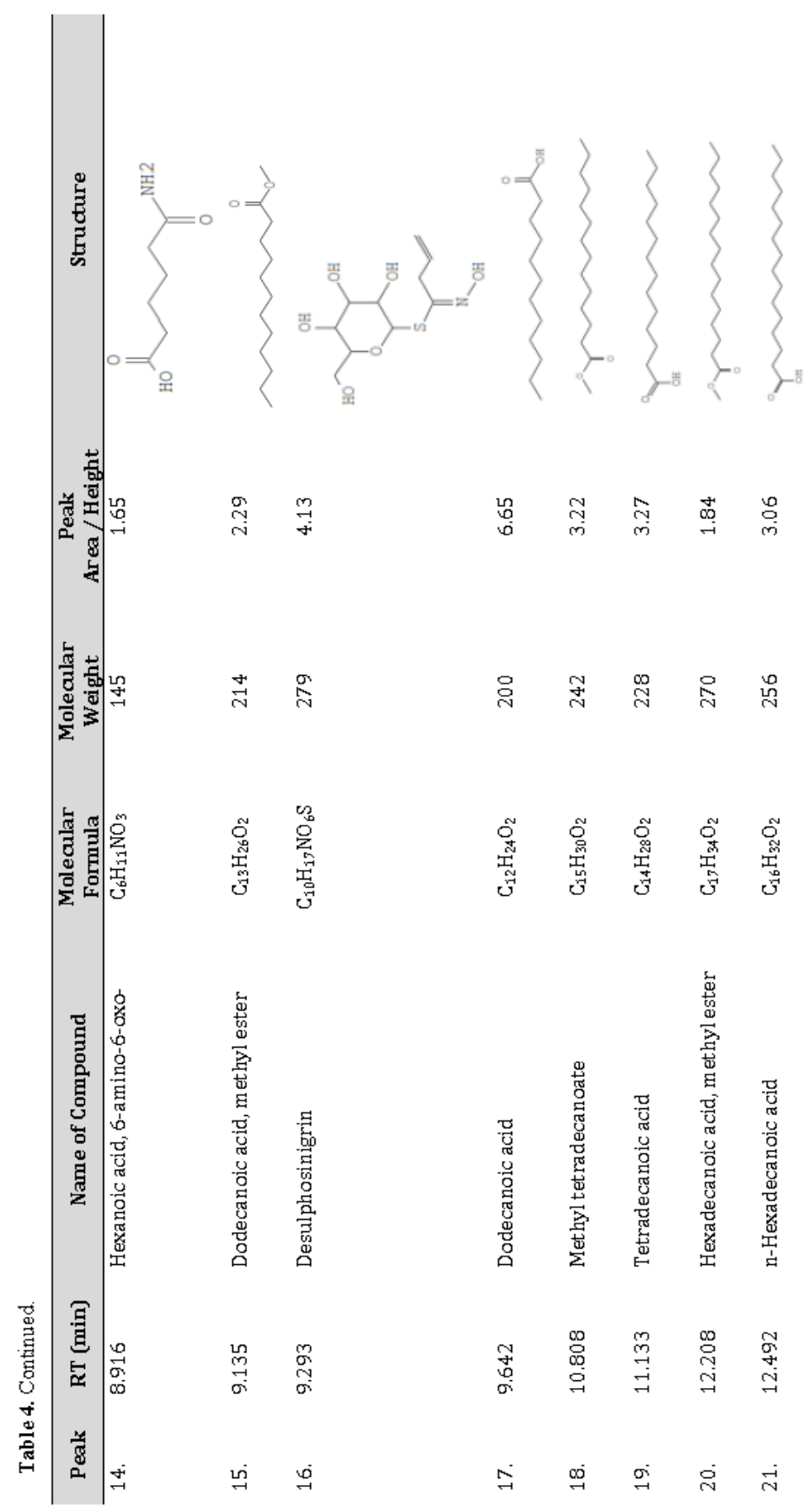

Braz. J. Biol. Sci., 2018, v. 5, No. 10, p. 373-404. 


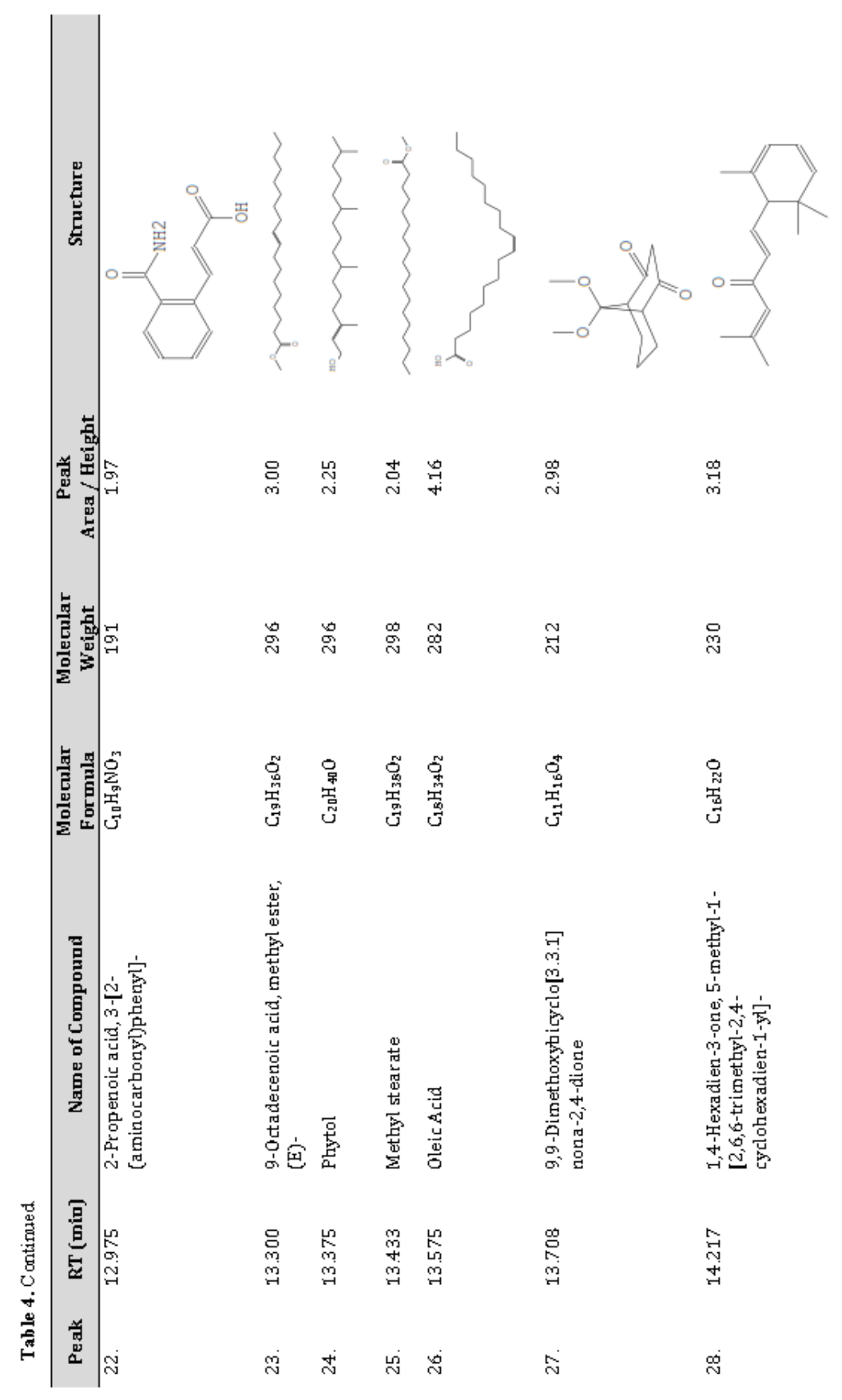

Braz. J. Biol. Sci., 2018, v. 5, No. 10, p. 373-404. 


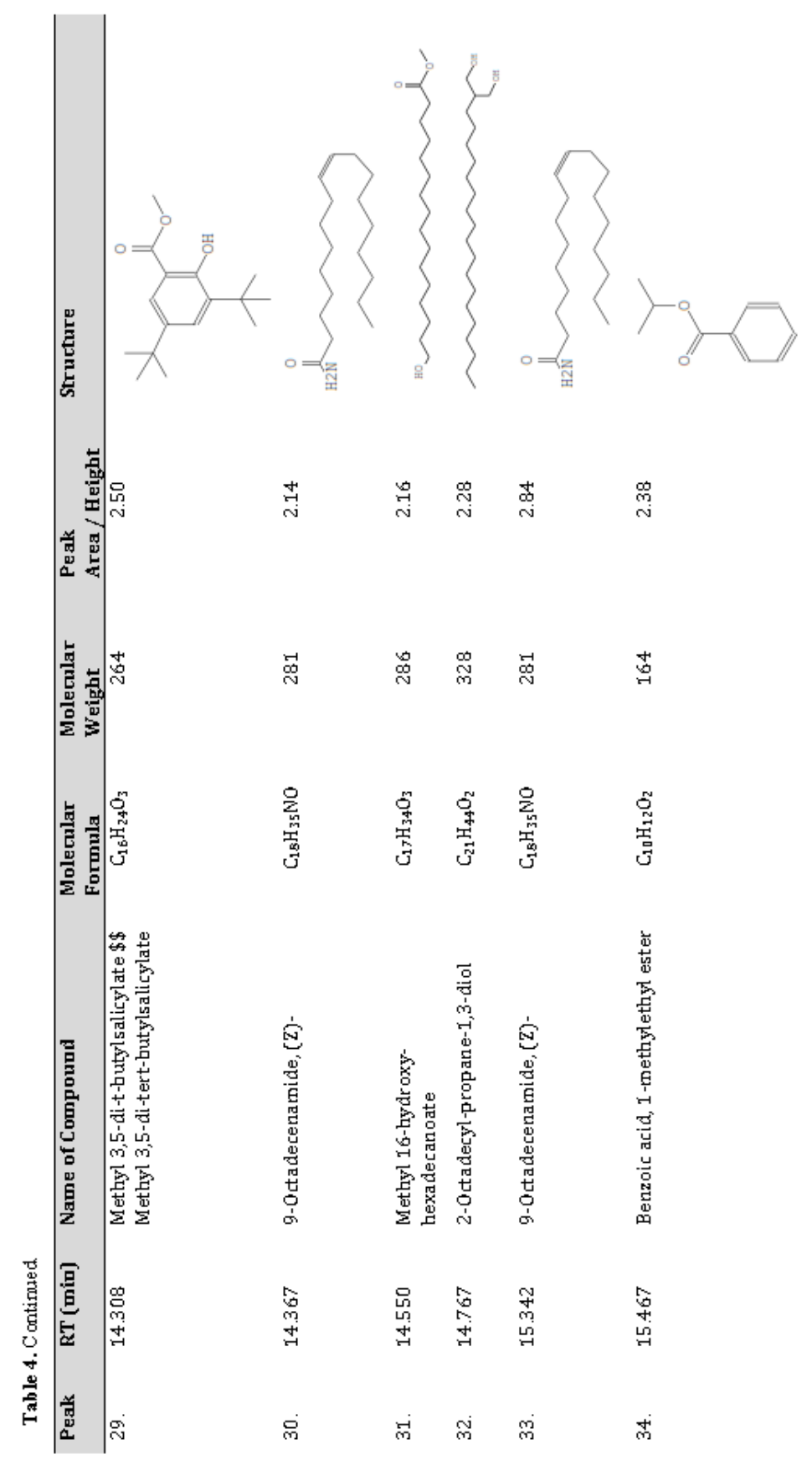

Braz. J. Biol. Sci., 2018, v. 5, No. 10, p. 373-404. 


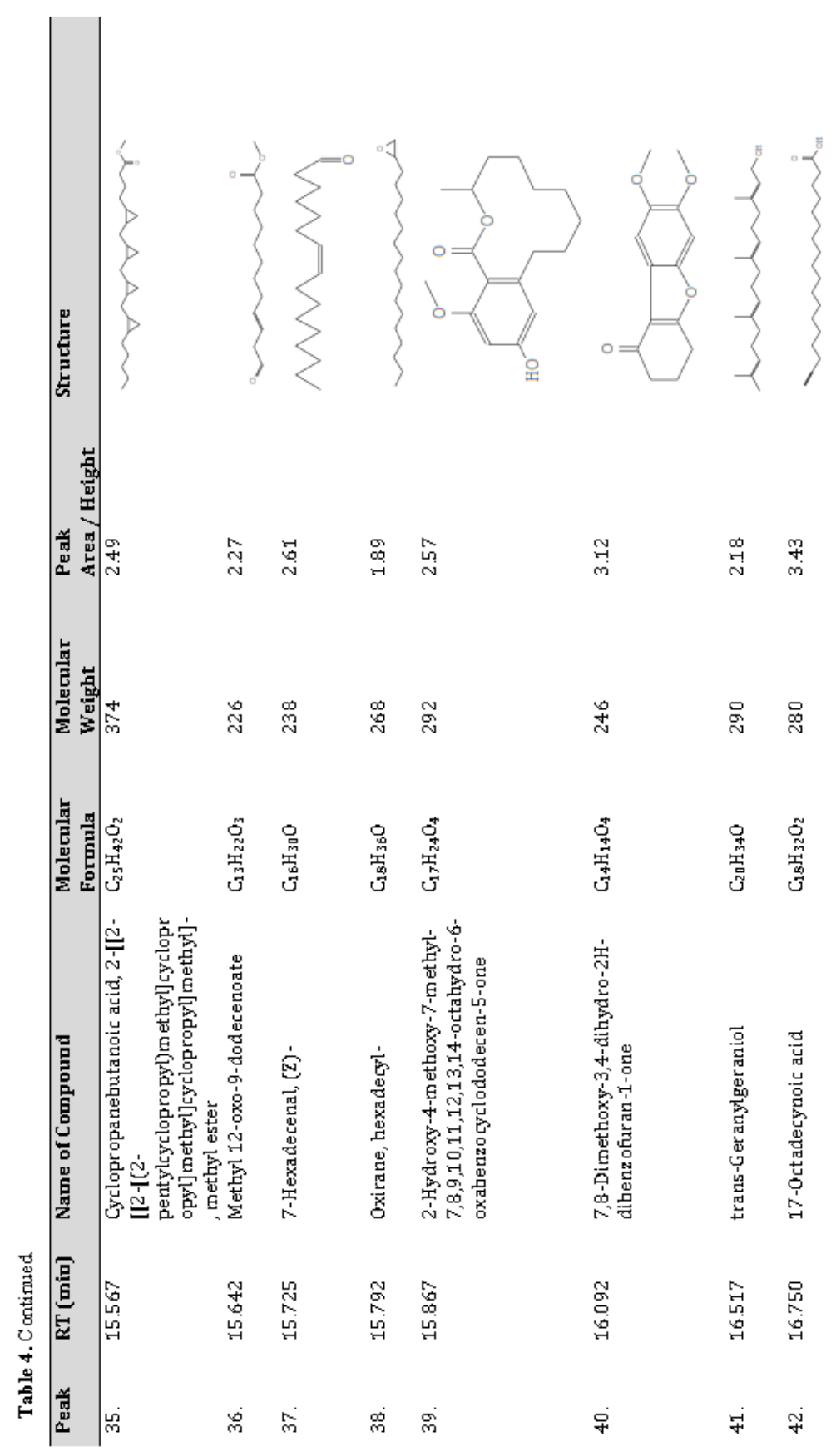

Braz. J. Biol. Sci., 2018, v. 5, No. 10, p. 373-404. 


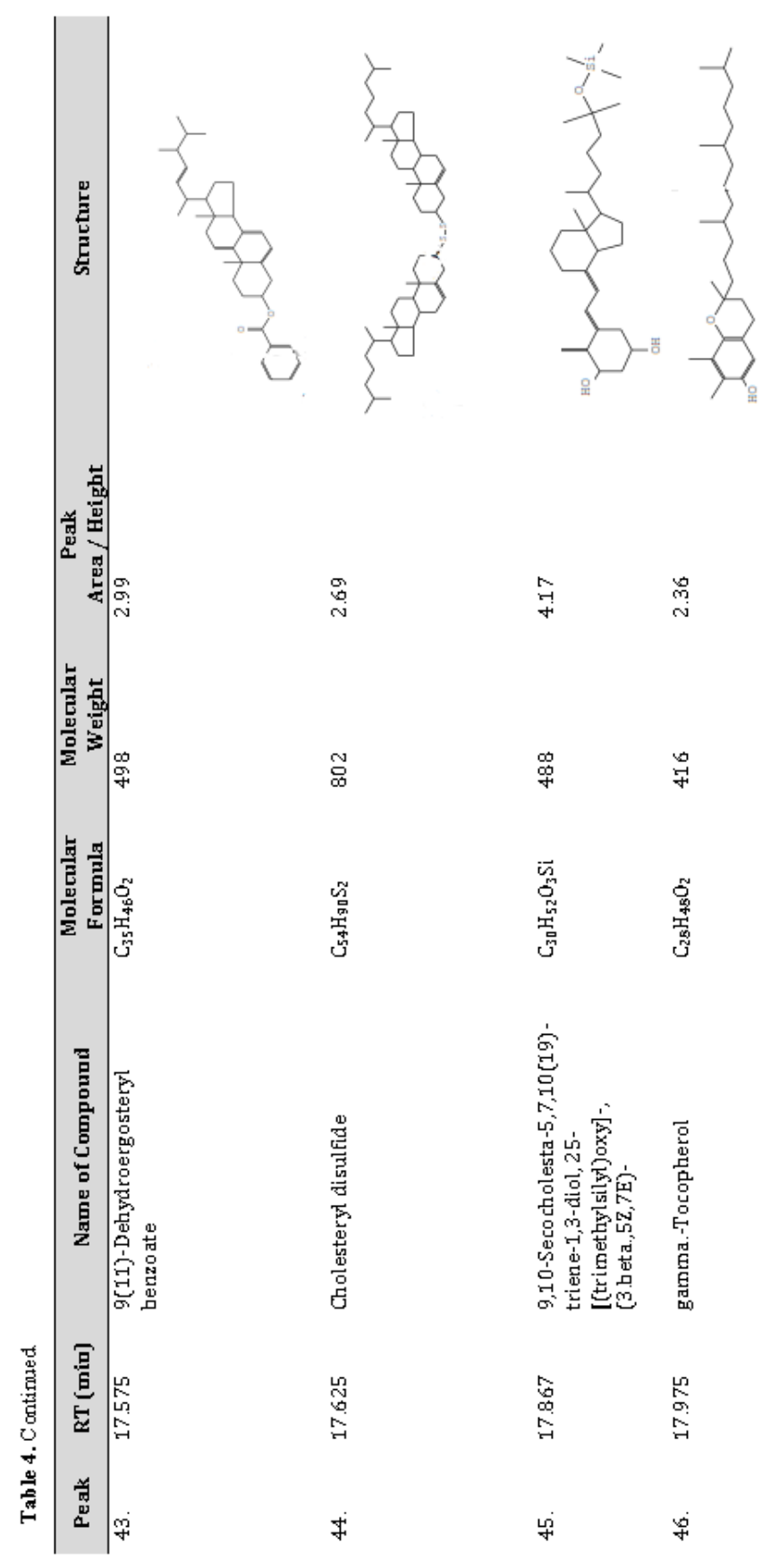

Braz. J. Biol. Sci., 2018, v. 5, No. 10, p. 373-404. 


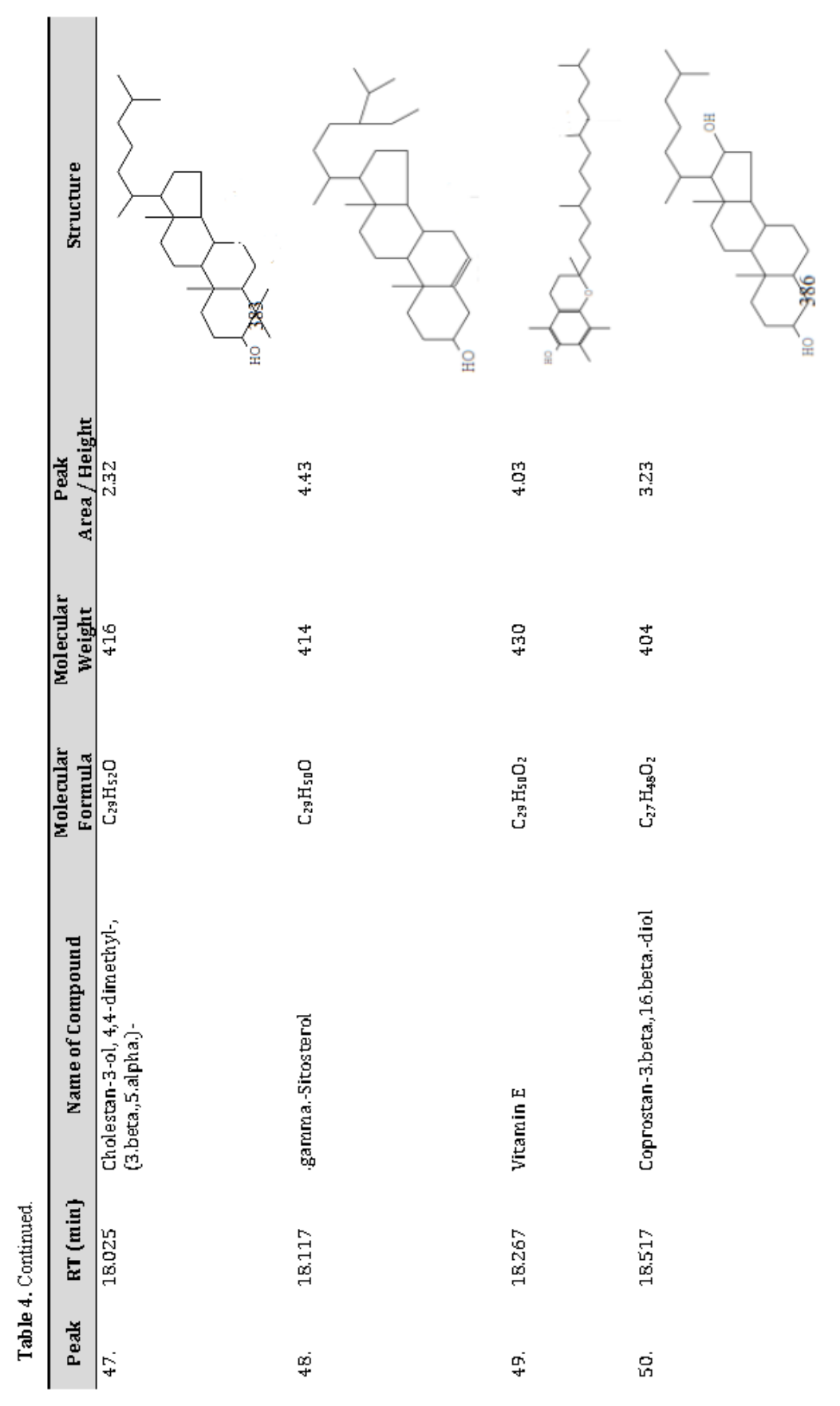

Braz. J. Biol. Sci., 2018, v. 5, No. 10, p. 373-404. 


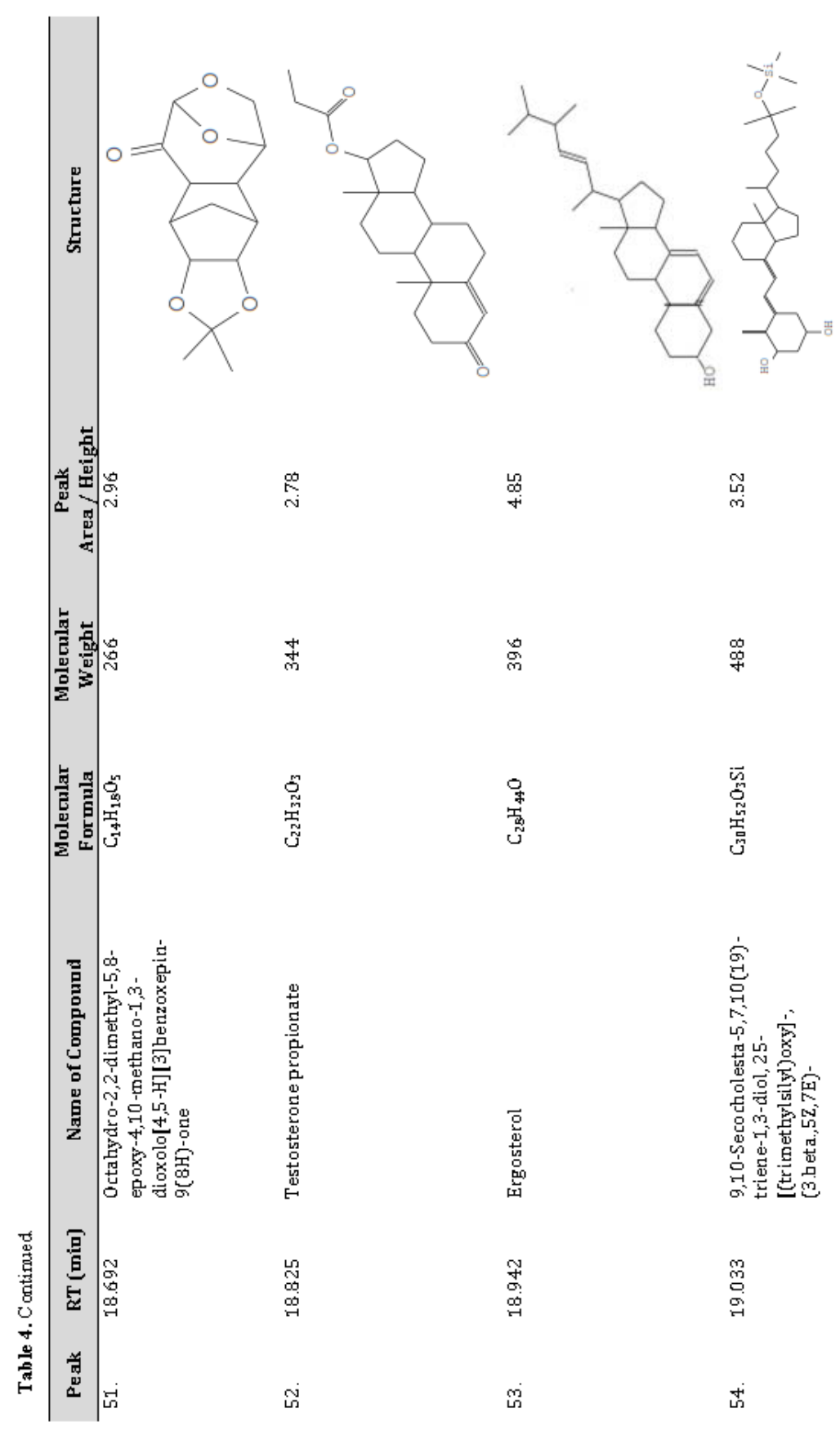

Braz. J. Biol. Sci., 2018, v. 5, No. 10, p. 373-404. 


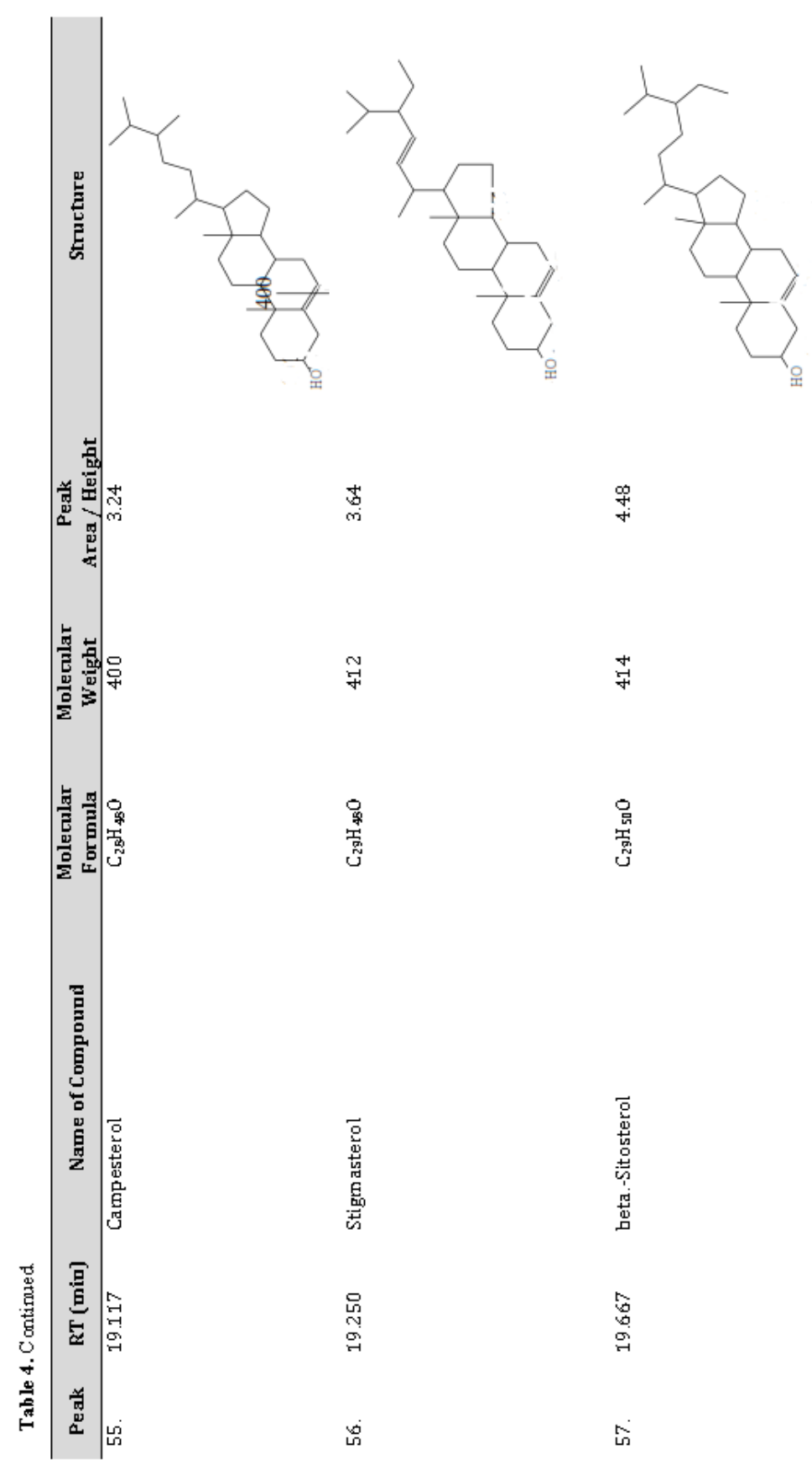

Braz. J. Biol. Sci., 2018, v. 5, No. 10, p. 373-404. 


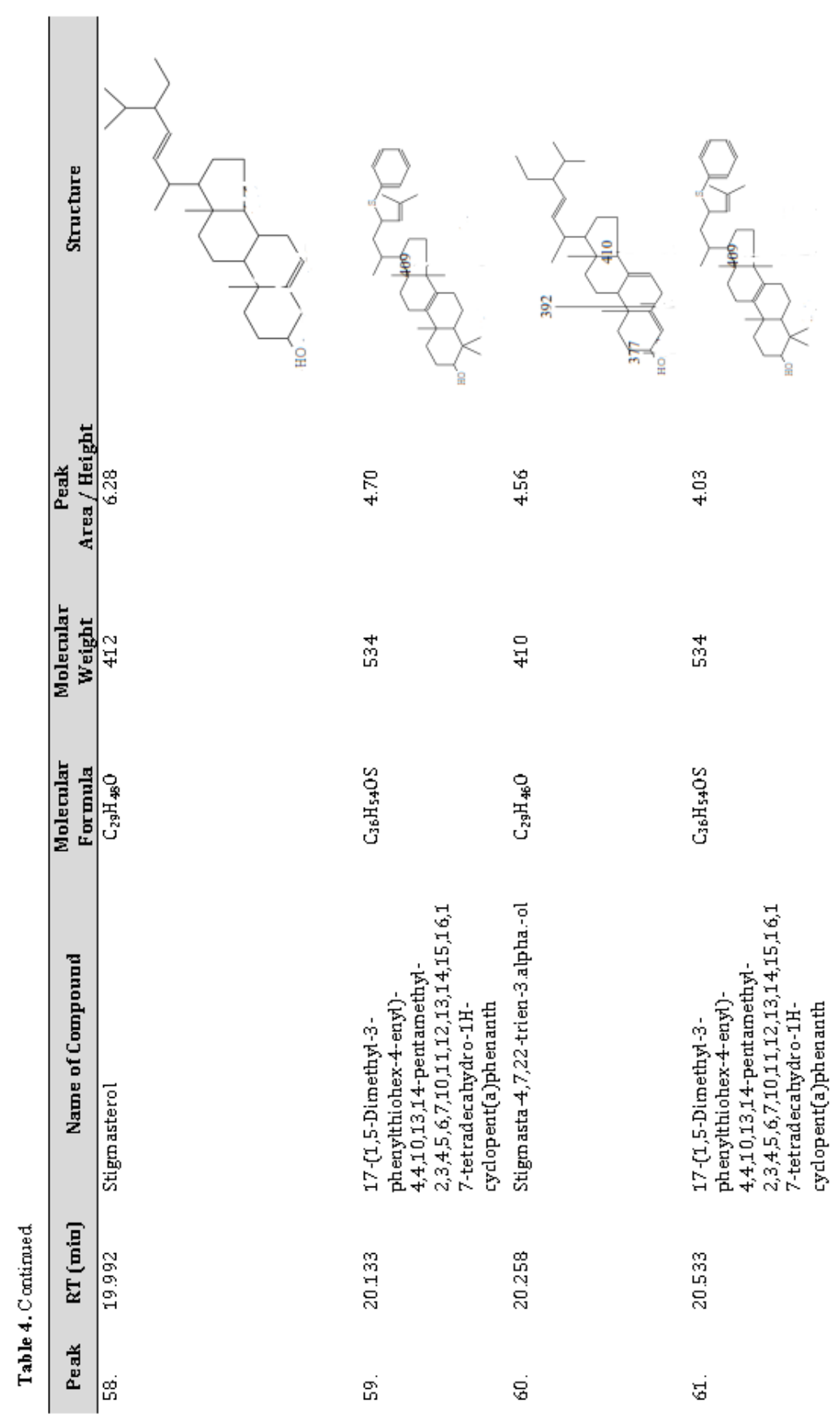

Braz. J. Biol. Sci., 2018, v. 5, No. 10, p. 373-404. 

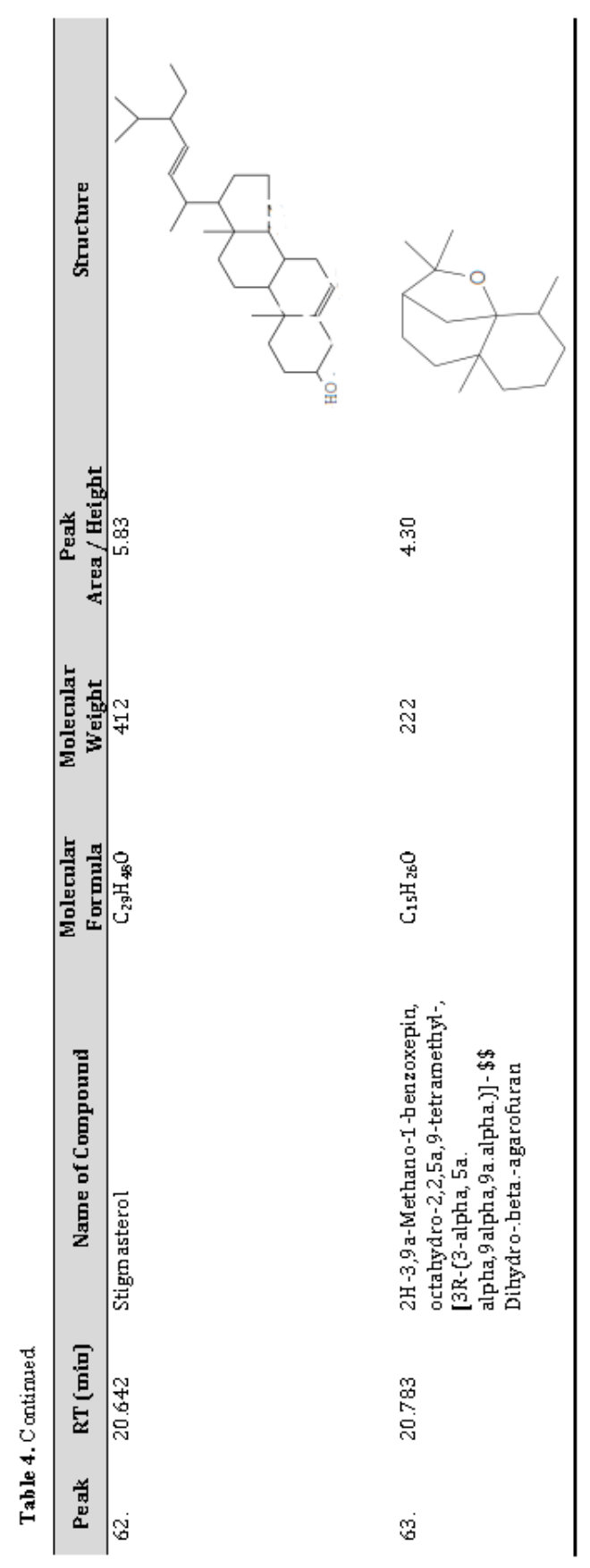

Braz. J. Biol. Sci., 2018, v. 5, No. 10, p. 373-404. 


\section{Antibacterial studies}

The n-hexane and aqueous extracts of Desplatsia dewevrei had no zone of inhibition at $300 \mathrm{mg} / \mathrm{mL}$.
Methanol extracts inhibited only the gram positive isolates and no zone of inhibition against the gram negative isolates as reported on Tables 5, 6 and 7.

Table 5. Results for sensitivity testing at $300 \mathrm{mg} / \mathrm{mL}$ of methanol extract.

\begin{tabular}{cccc}
\hline Bacterial isolates & Z.I $(\mathbf{m m})$ & Bacterial isolates & Z.I $(\mathbf{m m})$ \\
\hline Sa1 & 22 & Kleb1 & NZI \\
Sa2 & 22 & Kleb2 & NZI \\
Sa3 & 17 & Kleb3 & NZI \\
Sa4 & 19 & Ps1 & NZI \\
Sa5 & 19 & Ps2 & NZI \\
Sa6 & 20 & Ps3 & \\
Ec1 & NZI & & \\
Ec2 & NZI & \\
Ec3 & NZI & \\
Bs1 & 19 & & \\
Bs2 & 17 & & \\
Bs3 & 16 & & \\
Bs4 & 18 & & \\
\hline
\end{tabular}

Key: Sa - Staphylococcus aureus; EC- Escherichia coli; Bs- Bacillus subtilis; Kleb- Klebsiella species; Ps- Pseudomonas aeruginosa, NZI- No zone of inhibition

Table 6. Zones of inhibition of Methanol fruit extract on gram positive bacterial isolates

\begin{tabular}{lccccccc}
\hline $\begin{array}{c}\text { Gram } \\
\text { Positive } \\
\text { Isolates }\end{array}$ & $\mathbf{3 0 0}$ & $\mathbf{1 5 0}$ & $\mathbf{7 5}$ & $\mathbf{3 7 . 5}$ & $\mathbf{1 8 . 7 5}$ & $\mathbf{9 . 3 8}$ & $\mathbf{4 . 6 9}$ \\
\hline Sa1 & 22 & 21 & 20 & 20 & 19 & 17 & $\mathrm{NZ}$ \\
Sa2 & 22 & 21.5 & 20.5 & 20 & 19 & 18 & $\mathrm{NZ}$ \\
Sa3 & 17 & 16 & 14 & 12 & $\mathrm{NZ}$ & $\mathrm{NZ}$ & $\mathrm{NZ}$ \\
Sa4 & 19 & 17 & 15.5 & 15 & $\mathrm{NZ}$ & $\mathrm{NZ}$ & $\mathrm{NZ}$ \\
Sa5 & 19 & 18 & 15 & $\mathrm{NZ}$ & $\mathrm{NZ}$ & $\mathrm{NZ}$ & $\mathrm{NZ}$ \\
Sa6 & 20 & 18 & 15 & $\mathrm{NZ}$ & $\mathrm{NZ}$ & $\mathrm{NZ}$ & $\mathrm{NZ}$ \\
Bs1 & 19 & 17 & 16 & 15 & $\mathrm{NZ}$ & $\mathrm{NZ}$ & $\mathrm{NZ}$ \\
Bs2 & 17 & 15 & 13 & 12 & $\mathrm{NZ}$ & $\mathrm{NZ}$ & $\mathrm{NZ}$ \\
Bs3 & 16 & 13 & $\mathrm{NZ}$ & $\mathrm{NZ}$ & $\mathrm{NZ}$ & $\mathrm{NZ}$ & $\mathrm{NZ}$ \\
Bs4 & 18 & 15 & 12 & $\mathrm{NZ}$ & $\mathrm{NZ}$ & $\mathrm{NZ}$ & $\mathrm{NZ}$ \\
\hline
\end{tabular}

Key: Sa = Staphylococcus aureus; Bs = Bacillus subtilis; NZ=No zone of inhibition. 
Table 7. Zones of Inhibition of methanol leaf extract on gram positive bacterial isolates.

\begin{tabular}{lccccccc}
\hline $\begin{array}{c}\text { Gram } \\
\text { Positive } \\
\text { Isolates }\end{array}$ & $\mathbf{3 0 0}$ & $\mathbf{1 5 0}$ & $\mathbf{7 5}$ & $\mathbf{3 7 . 5}$ & $\mathbf{1 8 . 7 5}$ & $\mathbf{9 . 3 8}$ & $\mathbf{4 . 6 9}$ \\
\cline { 2 - 7 } Sa1 & 15 & 13 & $\mathrm{NZ}$ & $\mathrm{NZ}$ & $\mathrm{NZ}$ & $\mathrm{NZ}$ & $\mathrm{NZ}$ \\
Sa2 & 14 & 12 & $\mathrm{NZ}$ & $\mathrm{NZ}$ & $\mathrm{NZ}$ & $\mathrm{NZ}$ & $\mathrm{NZ}$ \\
Sa3 & 13 & $\mathrm{NZ}$ & $\mathrm{NZ}$ & $\mathrm{NZ}$ & $\mathrm{NZ}$ & $\mathrm{NZ}$ & $\mathrm{NZ}$ \\
Sa4 & 14 & 12 & $\mathrm{NZ}$ & $\mathrm{NZ}$ & $\mathrm{NZ}$ & $\mathrm{NZ}$ & $\mathrm{NZ}$ \\
Sa5 & 13 & $\mathrm{NZ}$ & $\mathrm{NZ}$ & $\mathrm{NZ}$ & $\mathrm{NZ}$ & $\mathrm{NZ}$ & $\mathrm{NZ}$ \\
Sa6 & 15 & 13 & $\mathrm{NZ}$ & $\mathrm{NZ}$ & $\mathrm{NZ}$ & $\mathrm{NZ}$ & $\mathrm{NZ}$ \\
Bs1 & 14 & 13 & $\mathrm{NZ}$ & $\mathrm{NZ}$ & $\mathrm{NZ}$ & $\mathrm{NZ}$ & $\mathrm{NZ}$ \\
Bs2 & 13 & $\mathrm{NZ}$ & $\mathrm{NZ}$ & $\mathrm{NZ}$ & $\mathrm{NZ}$ & $\mathrm{NZ}$ & $\mathrm{NZ}$ \\
Bs3 & 12 & $\mathrm{NZ}$ & $\mathrm{NZ}$ & $\mathrm{NZ}$ & $\mathrm{NZ}$ & $\mathrm{NZ}$ & $\mathrm{NZ}$ \\
Bs4 & 14 & 12 & $\mathrm{NZ}$ & $\mathrm{NZ}$ & $\mathrm{NZ}$ & $\mathrm{NZ}$ & $\mathrm{NZ}$ \\
\hline
\end{tabular}

Key: Sa = Staphylococcus aureus; Bs = Bacillus subtilis; NZ=No Zone of inhibition.

\section{Discussions}

\section{Qualitative phytochemistry}

Phytochemicals; which often display their health protective effects in diverse ways are non-nutritive plant chemicals that have protective or disease preventive properties (Omoregie and Osagie, 2012). Predominantly, phytochemicals are produced by plants to protect themselves from predation but, recent researchers demonstrate that they can also protect humans against diseases (Abuga, 2014; Edeoga et al., 2005; Idu, 2011). The phytochemicals found appreciably present in the leaves and fruits of Desplatsia dewevrei were cardiac glycoside, saponin, quinones, coumarins and phlobatannins (Table 1). Coumarins have been reported to possess the ability to stimulate macrophages, activate other cells of the immune system, and stabilise swellings (anti-inflammatory) (Thornes et al., 1982; Jain and Joshi, 2012). Coumarins can also be used not just to treat cancer but, to treat the side effects caused by radiotherapy (Agrawal, 2000). Coumarins are competitive inhibitors of Vitamin-KA in the synthesis of prothrombin (Weitz, 2006; Mirunalini et al., 2011). The presence of coumarin in D. dewevrei leaves suggests that the plant can stimulate cells of the immune system and generate an anti-inflammatory effect on man.

Phlobatannins are a type of tannins. Tannins have been reported to have antibacterial, anti-enzymatic and astringent properties (Machado et al., 2012). The ingestion of tannin can be used to treat diarrhoea (in the absence of fever or inflammation). The antioxidant and anti-mutagenic properties of tannic acid are beneficial. Externally, tannins can be used to treat ulcers, tooth aches and wounds. Tannins Unpleasant taste tans leather in the production of leather and ink; in haemorrhoids, frostbite and burns, Soothing relief, regenerates skin, anti-inflammatory, Diuretic (Okwu and Okwu, 2004). Tannins may be useful as anti-tumour, anticancer, antimicrobial and antiulcer agents (Rajeshwari and Andallu, 2011). The relatively abundant presence of tannic acid in Desplatsia dewevrei suggests the source of its antibacterial activity.

Saponins are emulsifying agent which have been implicated for use as expectorants, cough suppressants and for their haemolytic effect on red blood cells, perhaps because of their bitter taste and foaming property (Sofowora, 1993; Okwu, 2005). The appreciable presence of saponins in the leaves of $D$. dewevrei proposes that the plant may be used as cough suppressants. 
Quinones have also been used as taxonomic markers for bacterial (Collins and Jones, 1981; Hess et al., 1979). Natural or synthetic quinones are biologically or pharmacologically active as anti-tumoral agents, purgatives, antimicrobial, antiparasitic and anticardiovascular disease agents (Liu, 2011). Quinones are the compounds responsible for the browning reaction in cut or damaged fruits and vegetables. They are intermediates in the melanin synthesis pathway in the human skin (Abuga, 2014). These qualities of quinones suggest that $D$. dewevrei may be applicable in the treatment of bacterial infections and management of cardiovascular diseases because of the remarkable presence quinones in the fruits (Table 1).

Cardiac glycosides are useful to treat congestive cardiac arrhythmia leading to cardiac arrests/ failures (Vladimir and Ludmila, 2001). Cardiac glycosides have been demonstrated to exert antiproliferative and proapoptotic effects against neoplastic cells in vitro, singly (Joshi et al., 2011; Haux et al., 1999) and in combination with chemoand radiotherapy (Nasu et al., 2002; Wang et al., 2011) as they not only preferentially inhibit the growth of malignant cells but also promote the activation of tumor- specific immune responses (Menger et al., 2013). The presence of cardiac glycoside and the downward regulation of cancer biomarkers P53 in animals administered with Desplatsia dewevrei leaves may be a pointer to the possible anti-cancer activities of the plant.

Flavonoids which are water soluble, super free radical scavengers notable in the prevention of oxidative cell damage, as antioxidant, anticarcinogens, antimicrobial, antitumour agents (Kandaswami et al., 1994; Manikandan et al., 2006) were also found present in the leaves and fruits of Desplatsia dewevrei alongside phenols, Terpenoids, tannins, sterols and alkaloids which have their unique therapeutic applications.

\section{Quantitative phytochemistry}

Results from the quantitative phytochemistry studies reported in Table 2 suggests that the total phenolic content, total flavonoid content, total tannic acid content and total proanthocyanidin content of Desplatsia dewevrei are more abundantly present in the leaves than fruits of the plant. Polyphenolics help to quantify the primary antioxidants in medicinal plants (Iqbal et al., 2015). Among polyphenols, flavonoids are of great importance because they help the human body to fight against diseases. Flavonoids are abundantly found in plants as their glycoside (Rajanandh and Kavitha, 2010). The most abundant flavonol which has a good antioxidant property is quercetin, as it has all the right structural features for free radical scavenging activity (Kalita et al., 2013).

A gas chromatogram shows the relative concentrations of several compounds subjected to elucidation as a function of retention time. Peak heights indicate the relative concentrations of constituents present in the plant extract. Mass spectrometer analyzes the compounds eluted at different intervals to identify the nature and structure of the compounds (Kalimuthu and Prabakaran, 2013). Mass spectrometry fitted to a gas chromatograph was used in this study to get more precise information for qualitative analysis of the chemical compounds in Desplatsia dewevrei (Cong et al., 2007; Omoregie et al., 2015). Figures 1 and 2 show the gas chromatograms in the present study; a total of 33 peaks and 63 in the leaves and fruits of $D$. desplatsia.

Correlating phytochemical compounds with their biological and/or therapeutic activities is of the essence in harnessing any new compound for the purpose of drug discovery and development (Selvamangai and Bhaskar 2012; Omoregie et al., 2015). Most of the 
compounds got from the GC-MS analysis of $D$. dewevrei leaves and fruits were mainly fatty acids, diterpene alcohols, epoxides, fat soluble vitamin E, steroids and ketone fatty acid aldehydes in nature (Tables 3 and 4). These sorts of compounds have overwhelming therapeutic uses. For instance, "Phytol" which was found present as the highest peaked compound in the aqueous and methanol leaf extracts of Desplatsia dewevrei is a diterpene alcohol have been reported useful as an antibacterial active against Staphylococcus aureus, a precursor for Vitamins $\mathrm{E}$ and $\mathrm{K}$, effective at different stages of arthritis (Inoue et al., 2005). Also, diterpenoids have been reported to be useful chemotherapeutic agents (Kingston, 1992; Okigbo et al., 2009).Phytol was also found present in D. dewevrei methanol leaf extract. Phytol is useful as an antibacterial active against Staphylococcus aureus, a precursor for Vitamins E and K, effective.

The nature and therapeutic activities of nine compounds: $2 \mathrm{H}$-pyran2-one, tetrahydro-6-tridecyl-; 2pentadecanone,6,10,14-trimethyl-; cyclopropa[5,6]stigmast-22-en-3one,3',6-dihydro-,(5.beta.,6.alpha.,22E)-; 4,8,13-cyclotetradecatriene-1,3diol,1,5,9-trimethyl-12-(1-methylethyl)-; [1,1'-Bicyclohexyl]-4-carboxylic acid, 4'propyl-, 4-fluorophenyl ester; cyclohexanepropanol,.alpha.,2,2,6tetramethyl-; Z,Z-4,16-Octadecadien-1-ol acetate; Tridecanoic acid, 12-methyl-, methyl ester; and Tetradecenal could not be found on NIST, Pubchem or any other online chemical search engines and database libraries. Of the thirty-three (33) peaks representing various compounds depicted on the chromatogram of Desplatsia dewevrei methanol leaf extract, two peaks were recurring; peaks 7 and 18 were discovered to be the same compound (Cyclohexanepropanol alpha., 2,2,6tetramethyl) evolving at different retention time. Peaks 29 and 30 were also found to be Farnesyl bromide. The other thirty-one (31) compounds detected in this study are; Octanoic acid, methyl ester; Dodecanoic acid, methyl ester;Dodecanoic acid;Tridecanoic acid, 12-methyl-, methyl ester; Tetradecanoic acid; $\quad 3,7,11,15$-Tetramethyl-2hexadecen-1-ol; Z,Z-4,16-Octadecadien1-ol acetate; Tetradecanal; alpha.Tetralol, 2-amino-0-ethyl-; 2Pentadecanone, 6,10,14-trimethyl-; 9Hexadecenoic acid, methyl ester, (Z)-; Hexadecanoic acid, methyl ester; 9Octadecenoic acid, methyl ester, (E)-; Phytol; Methyl stearate; 4-(2,2,6Trimethyl-bicyclo[4.1.0]hept-1-yl)butan-2-one;Oxirane, hexadecyl-; 2HPyran-2-one, tetrahydro-6-tridecyl-; Heptadecanal; Spiro[androst-5-ene17,1'-cyclobutan]-2'-one, 3-hydroxy-, (3.beta.,17.beta.); 2H-1-Benzopyran-6-ol, 3,4-dihydro-2,8-dimethyl-2-(4,8,12trimethyltridecyl)-, [2R-[2R* $\left.\left.\left(4 \mathrm{R}^{*}, 8 \mathrm{R}^{*}\right)\right]\right]-$ ; 5,14,23-Octadecatrien-14,15-diol; .gamma.-Tocopherol; (.+/-.)-.alpha.Tocopherol acetate; [1,1'-Bicyclohexyl]4-carboxylic acid, 4'-propyl-, 4fluorophenyl ester; beta.Sitosterol;Cyclopropa[5,6]stigmast-22en-3-one, 3',6-dihydro-, (5.beta.,6.alpha.,22E)-; $\quad$ 4,8,13Cyclotetradecatriene-1,3-diol, 1,5,9trimethyl-12-(1-methylethyl)- and Acetic acid, 3-hydroxy-7-isopropenyl-1,4adimethyl-2,3,4,4a,5,6,7,8octahydronaphthalen-2-yl ester.

Antibacterial activities of Desplatsia dewevrei as evident from Tables 5, 6 and 7 shows that Desplatsia dewevrei is able to inhibit the activities of gram positive bacterial at extract concentrations above $150 \mathrm{mg} / \mathrm{mL}$. Zones of inhibition are not recorded for gram negative bacteria in this study. Also, the high concentration of tannic acid in the leaves of the plant maybe said to be the chief responsible factor for the antibacterial effect recorded in this study. However, further studies are recommended to test more gram positive bacteria and gram negative bacteria using other solvent extracts of Desplatsia dewevrei. 


\section{Conclusion}

Desplatsia dewevrei methanol leaf extract is rich in phyto-compounds. Although, many of these phytocompounds had known therapeutic uses, there were a few compounds which could not be matched with established chemical databases. These compounds may be investigated for their therapeutic and other biological activities then, incorporated into drug production.

\section{Conflicts of interest}

Authors declare that they have no conflict of interests.

\section{References}

Abok, J. I.; Manulu, C. TLC analysis and GC-MS profiling of hexane extract of Syzygium guineense leaf. Journal of Medicinal Plants Studies, v. 5, no. 1, p. 261-265, 2017.

Abuga, I. The Phytochemicals of Onion as affected by Inorganic Fertilizer. International Journal of Biological Sciences, v. 1, no. 5, p. 30-40, 2014.

Agrawal, M. S. BJR supplements and radiotherapy treatment planning data: $\mathrm{A}$ review. Journal of Medical Physics, v. 25, no. 1, p. 20-26, 2000.

AOAC - Association of Official Analytical Chemist. Official method of analysis. 18. ed. Maryland, USA: AOAC, 2005.

Boopathi, A. C.; Sivakumar, R. Phytochemical screening studies on the leaves and stem of Andrographis neesiana wight: An endemic medicinal plant from India. World Applied Science Journal, v. 12 , no. 3, p. 307-311, 2011.

Cicco, N.; Lanorte, M. T., Paraggio, M.; Viggiano, M.; Lattanzio V. A reproducible, rapid and inexpensive Folin-Ciocalteu Micro Method in determining phenolics of plant methanol extracts. Microchemical Journal, v. 91, p. 107-110, 2009.

Collins, M. D.; Jones, D. Distribution of isoprenoid quinone structural types in bacteria and their taxonomic implications. Microbiology Reviews, v. 45, p.316-354, 1981.
Cong, Z.; Meiling, Q. I.; Qinglong, S.; Shan, Z.; Ruonong, F. Analysis of the volatile compounds in Ligusticum chuanxiong Hort using HS-SPME-GCMS. J. Pharm. Biomed. Analysis, v. 44, p. 464-470, 2007.

Dhivya, M.; Kalaichelvi, K. Phytochemical studies and gas chromatography-mass spectrometry analysis of Sarcostemma brevistigma Wight and Arn. Asian Journal of Pharmaceutical and Clinical Research, v. 10, no. 3, p. 462-466, 2017.

Edeoga, H. O.; Okwu, D. E.; Mbaebie, B. O. Phytochemical constituents of some Nigerian medicinal Plants. African Journal of Biotechnology, v. 4, no. 7, p. 685-686, 2005.

Evans, W.C. Pharmacognosy. 14. ed. London: W.B. Sauders, 1996.

Harisaranraj, R.; Suresh, K.; Saravanababu, S. Evaluation of the chemical composition Rauwolfiaser pentina and Ephedra vulgaris. Advaced Biological Resource, v. 3, no. 56, p. 174-178, 2009.

Haux, J.; Lam, M.; Marthinsen, A. B. L.; Strickert, T.; Lundgren, S. Digitoxin, in nontoxic concentrations, induces apoptotic cell death in Jurkat T cells in vitro. Z Onkologie, v. 31, p 14-20, 1999.

Hess, A.; Hollānder, R.; Mannheim, W. Lipoquinones of some spore-forming rods, lactic-acid bacteria and actinomycetes. Journal of General Microbiology, v. 115, p. 247-252, 1979.

Hites, R. Gas chromatography mass spectroscopy. In: Settle, F. A. (Ed.). Handbook of instrumental techniques for analytical chemistry. Upper Saddle River, NJ: Prentice Hall PTR, 1997. p. 609-611.

Idu, M. The plant called medicine. Benin City, Edo State: Uniben Press, 2011.

Inoue Y.; Hada, T. A.; Shiraishi, K.; Hirore, H.; Hamashima; Kobayashi, S. Biphasic effects of geranylgeraniol, terpenone and phytol on the growth of Staphylococcus aureus. Antimicrob. Agents Chemother, v. 49, p. 1770-1774, 2005.

Iqbal, E.; Salim, K. A.; Lim, L. B. L. Phytochemical screening. Total phenolics and Antioxidant Activities of Bark and Leaf extracts of Goniothalamus velutinus (Airy Shaw) from Brunei Darussalam. Journal of King Saud University - Science, v. 27, p. 224-232, 2015. 
Iyamah, P.; Famuti, A.; Idu, M. GC-MS and Molecular docking studies for identification of anti-malarial compounds in Agbo-Iba PMII-a polyherbal formulation. Chemistry Research Journal, v. 2, no. 1, p. 46-56, 2017.

Jain, P. K.; Joshi, H. Coumarin: Chemical and pharmacological profile. Journal of Applied Pharmaceutical Science, v. 2, no. 6, p. 236240, 2012.

Joshi, A. D.; Parsons. D. W.; Velculescu, V. E.; Riggins, G. J. Sodium ion channel mutations in glioblastoma patients correlate with shorter survival. Molecular Cancer, v. 10, p. 17-19, 2011.

Kalimuthu, K.; Prabakaran R. Preliminary phytochemical screening and GC-MS analysis of methanol extract of Ceropegia pusilla. International Journal of Research in Applied, Natural and Social Sciences, v. 1, no. 3 , p. 49-58, 2013.

Kalita, P.; Barman, T. K.; Pal., T. K.; Kalita, R. Estimation of total flavonoids content (TFC) and antioxidant activities of methanolic whole plant extract of Biophytum sensitivum linn. Journal of Drug Delivery Therapy, v. 3, p. 33-37, 2013.

Kandaswami, C. E.; Perkins, D. S.; Solonink, G.; Arzewiecki, M. E. Anti-preventative effects of citrus flavonoids on human squamous cell carcinoma in vitro. Cancer Letter, v. 56, p. 147-152, 1994.

Keay, R. W. J. Trees of Nigeria. New York: Clarendon Press Oxford, 1989.

Kingston, D. G. I. Taxol and other anticancer agents from plants. In: Coombes, J. D. (Ed.). New drugs from natural sources. London: IBC Technical Services, 1992. p. 101-119.

Ladan, Z.; Amupitan, J. O.; Oyewale, O. A.; Ayo, R. G.; Temple, E.; Ladan, E. O. Phytochemical screening of the leaf extract of Hyptis spicigera plant. African Journal of Pure and Applied Chemistry, v. 8, no. 5, p. 83-88, 2014.

Liu, J.W.H. Extraction and isolation of compounds from herbal medicines. In: Liu, W. J. H. (Ed.). Traditional herbal medicine research methods: Identification, analysis, bioassay, and pharmaceutical and clinical studies. New York: John Wiley and Sons, 2011.
Machado, M.; Pires, P.; Dinis, A. M.; Santos Rosa, M.; Alves, V.; Salgueiro, L.; Cavaleiro, M. C.; Sousa, C.; Machado, M. Aldheides monoterpenes as potential anti-Leishmania agents: Activity of Cymbopongon citratus and citral on L. infantum, L. tropica and L. major. Experimental Parasitology, v. 5, p. 1-9, 2012.

Manikandan, L.; Senthilkumar, G. P.; Rajesh, L. T.; Suresh, R. Cancer chemopreventive agents from medicinal plants. In: Trivedi, P. C. Medicinal plants: Ethnobotanical approach. India: Agrobios, 2006.

Mathew, B.; Jatawa, S. K.; Tiwaari, A. Phytochemical analysis of Citrus limonum pulp and peel. International Journal of Pharmacy and Pharmaceutical Sciences, v. 4, n. 2, p. 269-371, 2012.

Menger, L.; Vacchelli, E.; Kepp, O.; Eggermont, A.; Tartour, E.; Zitvogel, L.; Kroemer, G.; Galluzzi, L. Trial watch: Cardiac glycosides and cancer therapy. Oncoimmunology, v. 2, no. 2, p. 23082-230827, 2013.

Miliauskas, G.; Vensketonis, P. R.; Van Beck, T. A. Screening of radical scavenging of some medicinal and aromatic plant extracts. Food Chemistry, v. 85, p. 231-237, 2004.

Mirunalini, S.; Krishnaveni, M.; Ambily, V. Effects of raw (Allium sativum) on hyperglycemia in patients with Type 2 Diabetes mellitus. Pharmacologyonline, v. 2, p. 968-974, 2011.

Nasu, S.; Milas, L.; Kawabe, S.; Raju, U.; Newman, R. (2002). Enhancement of radiotherapy by oleandrin is a cas-pase- 3 dependent process. Cancer Letter, 185: 14551.

Obadoni, B. 0.; Ochuko, P. O. Phytochemical studies and comparative efficacy of the crude extracts of some Homostatic plants in Edo and Delta states of Nigeria. Global Journal of Pure and Applied Sciences, v. 8, p. 203-208, 2001.

Okigbo, R. N.; Anuagasi, C. L.; Amadi, J. E. Advances in selected medicinal and aromatic plants indigenous to Africa. Journal of Medicinal Plants Research, v. 3, no. 2, p. 86-95, 2009. 
Okwu, D. E. Phytochemicals, vitamins and mineral content of two Nigerian medicinal plants. International Journal of Molecular Medicine and Advance Sciences, v. 1, no. 4, p. 375-381, 2005.

Okwu, D. E.; Okwu, M. E. Chemical composition of Spondia mombin plants. Journal of Sustainable Agriculture and the Environment, v. 6, p. 140-147, 2004.

Omoregie, E. S.; Osagie, A. U. Antioxidant properties of methanolic extracts of some Nigerian plants on nutritionally stressed rats. Nigerian Journal of Basic and Applied Science, v. 20, no. 1, p. 7-20, 2012.

Omoregie, G. O.; Idu, M.; Ovuakporie-Uvo, 0. GC-MS analysis of the aqueous extracts of Buchholzia coriacea Engl (Capparidaceae), seeds. International Journal of Life Science and Pharma Research, v. 5, no. 3, p. 26-32, 2015.

Osemeobo, G. J.; Ujor, G. The non-wood forest products of Nigeria. Data collection and analysis for sustainable forest management in ACP Countries - Linking National and International Efforts. Abuja, Nigeria: Federal Department of Forestry, 1999.

Ovuakporie-Uvo, O.; Idu M. Ethnobotanical knowledge of Desplatsia dewevrei (De Wild. \& T. Durand) Burret by the Bini Tribe, Edo State, Nigeria. Journal of Ayurvedic and Herbal Medicine, v. 3, no. 3, p. 129-132, 2017.

Ovuakporie-Uvo, O.; Idu M., Obarisiagbon, P.; Abode C. Analgesic, pro and anti inflammatory activities of Desplatsia dewevrei: Cytokine gene expression using Wistar rats and mice. Journal of Phytopharmacology, v. 7, no. 2, p. 185-190, 2018.

Pan, S.-Y;; Pan, S.; Yu, Z. L.; Ma, D. L; Chen, S. B.; Fong, W. F.; Han, Y. F.; Ko, K. M. New perspectives on innovative drug discovery: An overview. J. Pharm. Pharmaceut. Sci., v. 13, no. 3, p. 450-471, 2010.

Polshettiwar, S. A.; Ganjiwale, R. 0. Spectrophotometric estimation of total tannins in some Ayurvedic eye drops. Indian Journal of Pharmaceutical Sciences, v. 69, no, 4, p. 574-576, 2007.
Rajanandh, M. G.; Kavitha, J. Quantitative estimation of $\beta$-sitosterol, total phenolic and flavonoid compounds in the leaves of Moringa oleifera. International Journal of PharmTech Research, v. 2, p. 1409-1414, 2010.

Rajeshwari, C. U.; Andallu, B. Medicinal benefits of coriander (Coriandrum sativum L). Spatula DD, v. 1, p. 51-58, 2011.

Rajeswari, J.; Rani, S. GC-MS analysis of phytochemical compounds in the ethanolic extract of root of Lawsonia inermis Linn. International Journal of ChemTech Research, v. 7, no. 1, p. 389-399, 2015.

Riaz, T.; Muhammad, A. A.; Aziz-Ur-R.; Tayyaba, S.; Muhammad, A.; Khalid, M. K. Antioxidant activity and phenolic content of D. viscose. J. Serb. Chem. Soc., v. 77, no. 4, p. 423-435, 2012

Sathiyabalan, G.; Packia Lincy, M.; Muthukumarasamy, S.; Mohan, V. R. GC-MS Analysis of bioactive components of Petiveria alliacea L. Whole plant (Phytolaccaceae). International Journal of Pharma Research and Health Sciences, v. 2, no. 5, p. 387-392, 2014.

Selvamangai, G.; Bhaskar A. GC-MS analysis of phyto-components in the methanolic extract of Eupatorium triplinerve. Asian Pacific Journal of Tropical Biomedicine, v. 2, no. 3, Suppl., p.S1329-S1332, 2012. https://doi.org/10.1016/S2221-1691(12) 60410-9

Sofowora, E. A. Medicinal plants and Traditional Medicine in Africa. Ibadan, Nigeria: Spectrum Books, 1993.

Sofowora, E. A. Medicinal plants and Traditional Medicine in Africa. Nigeria: John Wiley and Sons, 2008.

Sun, B., Ricardo-da-Silva, J. M.; Spranger, I. Critical factors of vanillin assay for catechins and proanthocyanidins. Journal of Agricultural and Food Chemistry, v. 46, p. 4267-4274, 1998. https://doi.org/10.1021/ jf980366j

Thornes, R. D.; Lynch, G.; Sheehan, M. W. Relationship between structure and anticoagulant activity of coumarin derivatives. Lancet, v. 2, p. 328-339, 1982. 
Vladimir, K.; Ludmila, M. Glycosides in Medicine: The role of glycosidic residue in biological activity. Current Medical Chemistry, v. 8, p. 1303-1328, 2001.

Wang, L.; Raju, U.; Milas, L.; Molkentine, D.; Zhang, Z.; Yang, P., Cohen, L.; Meng, Z.; Liao, Z. Huachansu, containing cardiac glycosides, enhances radio-sensitivity of human lung cancer cells. Anticancer Research, v. 31, no. 6, p. 2141-2148, 2011.

Weitz, J. I. Blood coagulation and anticoagulant, thrombolytic and anti-platelet drugs. In: Brunton, L. L.; Chabner, B. A.; Knollmann, B. C. Goodman and Gilman's: The pharmacological basis of therapeutics. 11. ed. San Diego: McGraw-Hill, 2006. 